\title{
Aerosol shortwave direct radiative effect and forcing based on MODIS Level 2 data in the Eastern Mediterranean (Crete)
}

\author{
N. Benas ${ }^{1}$, N. Hatzianastassiou ${ }^{2}$, C. Matsoukas ${ }^{3}$, A. Fotiadi ${ }^{2}$, N. Mihalopoulos ${ }^{4}$, and I. Vardavas ${ }^{1}$ \\ ${ }^{1}$ Department of Physics, University of Crete, Greece \\ ${ }^{2}$ Department of Physics, University of Ioannina, Greece \\ ${ }^{3}$ Department of Environment, University of the Aegean, Greece \\ ${ }^{4}$ Environmental Chemical Processes Laboratory, Department of Chemistry, University of Crete, Greece
}

Received: 17 May 2011 - Published in Atmos. Chem. Phys. Discuss.: 12 July 2011

Revised: 20 October 2011 - Accepted: 25 November 2011 - Published: 15 December 2011

\begin{abstract}
The shortwave (SW) radiation budget was computed on a $10 \mathrm{~km} \times 10 \mathrm{~km}$ resolution above FORTH-CRETE AERONET station in Crete, Greece, for the 11-year period from 2000 to 2010. The area is representative of the Eastern Mediterranean region, where air pollution and diminishing water resources are exacerbated by high aerosol loads and climate change. The present study aims to quantify the aerosol direct effect and forcing on the local surface and atmospheric energy budget. A radiative transfer model was used, with climatological data from the Moderate Resolution Imaging Spectroradiometer (MODIS), on board NASA's Terra and Aqua satellites. The instantaneous radiative fluxes were computed for satellite overpass times at the surface, within the atmosphere and at the top of atmosphere (TOA). Downward surface fluxes and aerosol input data were validated against ground measurements. Output fluxes reveal the direct radiative effects of dust events, with instantaneous values reaching up to $-215,139$ and $-46 \mathrm{Wm}^{-2}$ at the surface (cooling), within the atmosphere (warming) and at TOA (cooling), respectively. Mean monthly values show a decreasing trend of the aerosol direct radiative effect, in agreement with a similar trend in AOT. The analysis of the contribution of anthropogenic and natural aerosol show major peaks of natural aerosol direct effect occurring mainly in spring, while a summer maximum is attributed to anthropogenic aerosol. During their peaks, anthropogenic aerosol forcing can reach values of $-24 \mathrm{Wm}^{-2}$ at the surface, $19 \mathrm{Wm}^{-2}$ in the atmosphere and over $-4 \mathrm{Wm}^{-2}$ at TOA
\end{abstract}

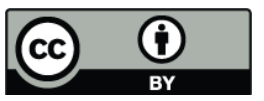

Correspondence to: N. Benas (benas@physics.uoc.gr) (monthly mean instantaneous values). The corresponding monthly peak values for natural aerosol are over $-20 \mathrm{Wm}^{-2}$, $12 \mathrm{Wm}^{-2}$ and $-9 \mathrm{Wm}^{-2}$.

\section{Introduction}

Solar energy, the main source of energy for life on Earth, enters within the Earth-atmosphere system, where it is redistributed. Subsequently, the planet emits radiation back to space at longer wavelengths. The Earth's Radiation Budget (ERB), the result of this procedure, regulates the climate and is an indicator of potential climatic changes. Thus, knowledge and monitoring of the ERB is crucial for improving our understanding of the Earth's climate and its possible changes (IPCC, 2007).

Amongst the different factors that can cause climate change, both greenhouse gases and aerosols play an important role. However, the quantification of the aerosol effects is more complex than the quantification of radiative forcing by greenhouse gases, because aerosol mass, chemical composition and particle number concentrations are highly variable in space and time, due to their much shorter atmospheric lifetime compared with the important greenhouse gases (e.g. Kaufman et al., 2002), the huge number of aerosol sources and the modification processes which change their properties. Better estimates of the aerosol radiative effects are required to reduce these uncertainties.

To reproduce successfully the distribution of the shortwave (SW) radiation budget through modeling studies on a local or regional scale, a complete description of the processes that govern the transfer of solar radiation within the

Published by Copernicus Publications on behalf of the European Geosciences Union. 
Earth-atmosphere system is required, together with moderate to high resolution comprehensive data sets for the key surface and atmospheric parameters. The Moderate Resolution Imaging Spectroradiometer (MODIS) instrument, on board NASA's Terra and Aqua satellites, provides most of the data sets needed for modeling the SW effects of aerosols (Chu et al., 2003; King et al., 2003; Remer et al., 2005). MODIS Level 2 data are provided each day at $10 \mathrm{~km} \times 10 \mathrm{~km}$ latitude-longitude resolution.

Several studies indicate that the aerosol direct radiative effect (DRE) over the Mediterranean is among the highest in the world, especially during summer (Andreae et al., 2002; Formenti et al., 2001). The entire Mediterranean lower troposphere is polluted, although the source regions differ from west to east (Lelieveld et al., 2002; Mihalopoulos et al., 1997). Formenti et al. (2001) and Andreae et al. (2002) related enhanced aerosol load to transport of air masses from western and eastern Europe and high-altitude transport of mineral dust from northern Africa. Bergamo et al. (2008) examined aerosol properties from six AERONET stations in the Mediterranean and showed that a mixture of anthropogenic and natural aerosols characterize the aerosol load over Crete, in the central-east Mediterranean basin. The studies of Fotiadi et al. (2006) and Kalivitis et al. (2007), also revealed a great variety of aerosol types over the region of Crete, including dust, urban-industrial, biomass-burning pollution and maritime, as well as mixed aerosol types. These aerosol properties, combined with the large solar insolation of the area, make Crete an ideal location to infer the range of aerosol DRE depending on their types. The aim of the present study is to present a new method for assessing aerosol effect and forcing on local scales, based on satellite data. This method can be applied in any region where these data are temporally and spatially sufficient. The area of Crete and the FORTH-CRETE AERONET station have been selected due to the unique aerosol characteristics of the wider Eastern Mediterranean region and for validation of the model input and output data against ground measurements.

We focus on the DRE of aerosols, which is the overall effect of natural plus anthropogenic aerosols, and the direct radiative forcing (DRF), which is the effect of anthropogenic aerosols only, on the radiative energy budget. The DRE and forcing of aerosols are computed in the SW range of wavelengths. The corresponding effect is much smaller in the LW (thermal infrared), due to the rapid decrease of aerosol extinction with increasing wavelength for most aerosol types. We use MODIS Level 2 Collection 051 data separately from Terra and Aqua satellites, and detailed spectral radiative flux calculations performed with a radiative transfer model. The deterministic radiative transfer model is used to compute the local distribution of all shortwave radiation budget components above FORTH-CRETE AERONET station in Crete. The radiation budget components are calculated on an instantaneous basis (satellite overpass time), spanning the 11-year period from February 2000 through December 2010.
In the next section, the model and the methodology for deriving the aerosol radiative properties are described. Section 3 describes the model input data and the station data used for the validation of the model. The procedure for the validation of the MODIS derived aerosol data against FORTHCRETE AERONET station measurements, the model sensitivity analysis performed and the model results are given in Sect. 4 , before the summary and conclusions.

\section{Model and methodology description}

We use a deterministic spectral radiative transfer model developed from a spectral radiative-convective model (Vardavas and Carver, 1984). Previous, spectral or simpler (broadband) versions of the model have been used by Vardavas and Koutoulaki (1995), Hatzianastassiou and Vardavas (1999, 2001) and Hatzianastassiou et al. (2004a, b, 2005, 2007), to compute the shortwave (SW) radiation budget and the aerosol direct radiative effect on global scales (see also Vardavas and Taylor, 2011).

The incoming solar irradiance at the top of the atmosphere is computed based on the spectral profile of Gueymard (2004), using a solar constant $\mathrm{S}_{0}=1367 \mathrm{Wm}^{-2}$ (Hartmann, 1994; Willson, 1997) corrected for the Earth's elliptical orbit, as explained by Hatzianastassiou et al. (2004a). The computations are performed separately for 118 wavelengths in the range $0.2-1.0 \mu \mathrm{m}$, and 10 spectral bands in the range $1.0-10 \mu \mathrm{m}$. For each wavelength and spectral band, a set of monochromatic radiative flux transfer equations is solved for an absorbing and multiple-scattering atmosphere, using the Delta-Eddington approximation method (Joseph et al., 1976) based on the Henyey-Greenstein phase function, which is an extension of the Eddington method described in Shettle and Weinmann (1970). According to Joseph et al. (1976), the Delta-Eddington method predicts the radiative fluxes to an accuracy of better than $2.5 \%$, with the average flux error being no larger than $0.5 \%$. Errors tend to increase as the cosine of the solar zenith angle $(\mu)$ decreases, but for values of $\mu \geq 0.4$ the errors remain at their lowest levels. In the present study, the cosine of the solar zenith angle is always greater than 0.5 .

The model takes into account physical parameters and processes that affect significantly the solar radiation transfer: absorption by $\mathrm{O}_{3}$ in the UV region between 0.2 and $0.35 \mu \mathrm{m}$ (Hartley-Huggins bands) and in the visible, between 0.45 and $0.85 \mu \mathrm{m}$ (Chappuis bands), and absorption in the near-infrared by water vapor $\left(\mathrm{H}_{2} \mathrm{O}\right)$, methane $\left(\mathrm{CH}_{4}\right)$ and carbon dioxide $\left(\mathrm{CO}_{2}\right)$. The model also includes scattering and absorption by clouds and aerosols, Rayleigh scattering and surface reflection. Ozone absorption cross section data are obtained from Sander et al., (2006). Details on the absorption of the molecules considered in the near infrared bands can be found in Vardavas and Taylor (2011) and Vardavas and Carver (1984). Cloud absorption 
and scattering optical depths are calculated as described in Sect. 3.3, while the corresponding absorption and scattering optical depths for aerosols are evaluated using aerosol optical thickness and single scattering albedo data. Computations of the Rayleigh scattering cross sections for the molecules considered are performed as described in Vardavas and Taylor (2011), p. 177.

Depending on the part of the solar spectrum considered, the atmosphere is divided into different number of layers which determine the solar radiation transfer. In the UVvisible region, five layers are considered: an aerosol layer above the Earth's surface, Rayleigh scattering layers below and above a cloud layer and an ozone layer at TOA. In the near-infrared part the layers are: $\mathrm{CO}_{2}$ and $\mathrm{H}_{2} \mathrm{O}$ absorbing layers above and below clouds and a scattering and absorbing aerosol layer above the surface. More details on this procedure can be found in Vardavas and Koutoulaki (1995) and Hatzianastassiou and Vardavas (1999). Aerosols within and above clouds are not considered in this study, due to missing information. This introduces an underestimate of the aerosol effect in the case of absorbing aerosols above clouds (Keil and Haywood, 2003). In the present study, an aerosol layer above clouds could exist during a Saharan dust event, when the aerosol layer extends up to $7 \mathrm{~km}$ in height (Meloni et al., 2005). However, the MODIS algorithm does not retrieve aerosol properties if a cloud is detected (Remer et al., 2005).

Reflection of incident solar radiation from the Earth's surface is taken into account and the surface reflectivity, $R_{\mathrm{g}}$, is treated as explained by Hatzianastassiou et al. (2004a). In our case, the radiative computations are performed over two coastal areas. We thus consider two types of surface, land and ocean, so that $R_{\mathrm{g}}=0.5 R_{\text {land }}+0.5 R_{\mathrm{o}}$. The ocean reflectivity, $R_{0}$, is computed using Fresnel reflection corrected for a non-smooth surface (Vardavas and Taylor, 2011). In the case of land, MODIS Level 2 data products include mean surface reflectance estimated at 7 wavelengths, which is used as input to the model, as explained in Sect. 3.4.

The SW aerosol DRE (denoted henceforth as $\Delta \mathrm{F}$ ) is the direct effect of aerosols on the SW radiation budget at the top of atmosphere (TOA), at the Earth's surface and within the atmosphere, and is given by

$\Delta F=F-F_{\text {no-aerosol }}$

where $F$ and $F_{\text {no-aerosol }}$ are the $\mathrm{SW}$ radiative fluxes $\left(\mathrm{Wm}^{-2}\right)$ computed with and without aerosols. The computations of the model are based on the shortwave radiation budget of the planet, whereby the net TOA incoming radiation equals the atmospheric plus the surface absorption. Model output includes TOA incoming radiation, TOA outgoing, atmospheric absorption, downwelling SW radiation (DSR), surface absorption and Net TOA incoming radiation. Our evaluation of the DRE emphasizes on the components of the radiation budget, namely the net TOA incoming radiation, the atmospheric absorption and the surface absorption, as well as the
DSR, which is a crucial component and can be directly validated against in situ measurements. The DRE components $\Delta F_{\mathrm{TOA}}, \Delta F_{\mathrm{AtmAb}}, \Delta F_{\text {Surface }}$ and $\Delta F_{\text {NetSurface }}$, represent the direct effect of aerosols on the net incoming (absorbed) radiation at TOA, within the atmosphere, and at the Earth's surface (DSR and surface absorption). As far as $\Delta F_{\mathrm{TOA}}$ is concerned, DRE is essentially the change of the outgoing (reflected) SW radiation at TOA, since the incoming extraterrestrial SW radiation is not affected by aerosols, and therefore $\Delta F_{\mathrm{TOA}}$ will refer to this henceforth, computed according to

$\Delta F_{\mathrm{TOA}}=F_{\text {no- aerosol }}^{\mathrm{TOA}}-F^{\mathrm{TOA}}$.

Therefore, positive values of $\Delta F$ correspond to decreased outgoing SW radiation at TOA and vice versa.

In the present study, a new version of the model was developed to incorporate the latest available satellite data, namely Level 2 data from the MODIS sensors on board NASA's Terra and Aqua satellites. The model spatial resolution was increased, reaching up to $5 \mathrm{~km} \times 5 \mathrm{~km}$ pixel size, depending on the resolution of the MODIS input data. Spatial resolutions of previous versions of the model were $2.5^{\circ} \times 2.5^{\circ}$ and $1^{\circ} \times 1^{\circ}$ latitude-longitude. The present high spatial resolution offers the possibility of distinguishing patterns that could not be obvious in studies where the resolution was lower, improving also the procedure of model validation against station measurements. The new version is also adjusted to run in two separate modes, one for the evaluation of mean daily results and another for computations regarding the specific satellite overpass time. Results from the second mode only were used in the present study. Modifications were also made to exploit the spectral resolution available from MODIS, regarding aerosol parameters (Aerosol Optical Thickness (AOT) and asymmetry factor $(\mathrm{g}))$ and the surface reflectance. The model uses MODIS data for clouds and other surface and atmospheric parameters (see Sect. 3). The data from MODIS are supplemented by aerosol single scattering albedo data, taken from FORTH-CRETE AERONET station, located on the roof of the $20 \mathrm{~m}$ high building of the Hellenic Center for Marine Research (HCMR), which is $100 \mathrm{~m}$ from the coast and $15 \mathrm{~km}$ east from Heraklion, the largest city in Crete. The model computations for SW fluxes are validated against 6-year (2003-2008) measurements from HCMR meteorological station (which is collocated on the northern coast of Crete, with the FORTH-CRETE AERONET station, at $35^{\circ} 19^{\prime} 58^{\prime \prime} \mathrm{N}$, $25^{\circ} 16^{\prime} 55^{\prime \prime} \mathrm{E}, 20 \mathrm{~m}$ altitude), and from Finokalia meteorological station $\left(35^{\circ} 20^{\prime} \mathrm{N}, 25^{\circ} 40^{\prime} \mathrm{E}, 150 \mathrm{~m}\right.$ altitude, with measurements spanning the period 2001-2007), which is also located at the northern coast of Crete, about $70 \mathrm{~km}$ east from Heraklion (Fig. 1). These comparisons ensure the quality of the long-term model results over the wider area, which is a prerequisite for the quality of aerosol DREs and DRFs. Model input data are described in detail in the next section. Finally, aerosol fine mode fraction, computed from MODIS AOT and fine mode AOT data, was used to separate the DRF 

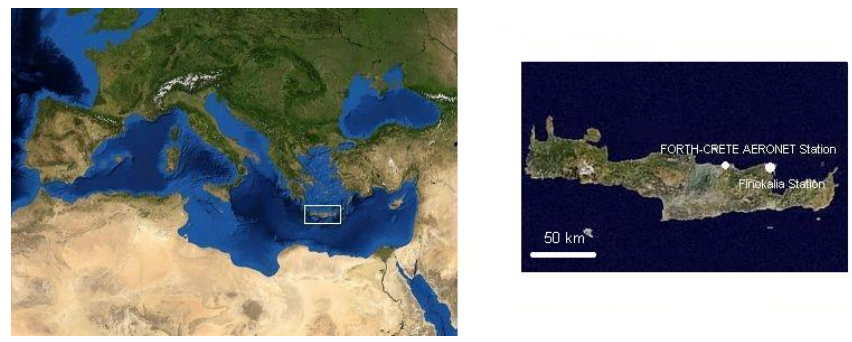

Fig. 1. The Mediterranean basin and the sites of FORTH-CRETE AERONET and Finokalia Stations, on the island of Crete.

Table 1. Input data required to model the shortwave radiation budget.

\begin{tabular}{lll}
\hline $\begin{array}{l}\text { Cloud } \\
\text { Properties }\end{array}$ & $\begin{array}{l}\text { Atmospheric } \\
\text { Properties }\end{array}$ & $\begin{array}{l}\text { Surface } \\
\text { Properties }\end{array}$ \\
\hline Cloud amount & Temperature & Pressure \\
Cloud scattering optical & Specific humidity & Temperature \\
depth & Atmospheric gases & Albedo \\
Cloud absorption optical & Aerosol optical depth & \\
depth & Aerosol asymmetry & \\
Cloud-top pressure & parameter & \\
Cloud physical & Aerosol single & \\
thickness & scattering & \\
Cloud phase & albedo & \\
\hline
\end{tabular}

from the DRE, as described in Sect. 4.5. The model was run for all days of each year of the study period (February 2000-December 2010). This time period is long enough to allow the examination of possible trends, while the temporal resolution (instantaneous values) allows the evaluation of events characteristic of the aerosol typical life time (e.g. dust events).

\section{Model input data}

In order to calculate the shortwave radiation budget using the model described above, various atmospheric, cloud and surface properties are required. These are listed in Table 1.

The input data needed are available separately from the Terra and Aqua MODIS instruments, except for the aerosol single scattering albedo, which is taken from the FORTHCRETE AERONET Station. MODIS Level 2 Collection 051 data come on a daily basis, at a $10 \mathrm{~km} \times 10 \mathrm{~km}$ and $5 \mathrm{~km} \times 5 \mathrm{~km}$ resolution for aerosol and all the other data, respectively. The data correspond to the specific overpass time of each satellite, which ranges from 10:20-12:00 for Terra and from 12:40-14:20 for Aqua (local time). MODIS Terra covers the period from February 2000, while MODIS Aqua data are available from July 2002. The model was run separately with Terra and Aqua MODIS input data, and the results correspond to the instantaneous satellite overpass times.

\subsection{Profiles of atmospheric gaseous pollutants and temperature}

MODIS provides data of the total $\mathrm{O}_{3}$ column abundance in Dobson units. For $\mathrm{CO}_{2}$ a total atmospheric amount is taken equal to $0.59 \mathrm{~g} \mathrm{~cm}^{-2}$, corresponding to a fixed mixing ratio of 379 parts per million by volume (ppmv) (2005 value). Similarly, we set the mixing ratios of $\mathrm{CH}_{4}$ and $\mathrm{N}_{2} \mathrm{O}$ equal to 1.774 and 0.319 ppmv, corresponding to $10^{-3}$ and $4.98 \times 10^{-4} \mathrm{~g} \mathrm{~cm}^{-2}$, respectively (Forster et al., 2007). Specific humidity and atmospheric temperature data are used to compute the total atmospheric water vapor content. The data of atmospheric temperature and dew point temperature, provided by MODIS at surface and at various atmospheric pressure levels up to the stratosphere, are used for the computation of the corresponding specific humidity profiles. The total atmospheric water vapor content $\left(\mathrm{g} \mathrm{cm}^{-2}\right)$ is calculated from

$W=-\int_{p_{g}}^{0} \eta(p) d p / g$

where $\eta(p)$ is the water mixing ratio by mass (from the specific humidity), $g$ is the gravitational acceleration and $p$ the atmospheric pressure (Vardavas and Taylor, 2011). For the computation of the integral, the twenty atmospheric levels available from the MODIS Atmospheric Profile product are used.

\subsection{Surface properties}

MODIS provides all the surface properties required by the model (pressure, temperature and albedo). The land-surface albedo is given at seven wavelengths $(0.47,0.55,0.66,0.87$, $1.24,1.64$ and $2.13 \mu \mathrm{m}$ ), while the ocean reflectivity is computed using Fresnel reflection, as explained in Sect. 2. In order to examine the spectral behavior and intra-annual variability of the land-surface albedo, we have calculated 9-year seasonal averages from the daily data. Figure 2 shows the mean land-surface albedo values at the given wavelengths, for the HCMR meteorological station area in Crete, averaged over the 9-year period 2000-2008, separately from Terra and Aqua MODIS instruments, for summer (JJA) and winter (DJF) months. A model sensitivity test was also performed, showing a difference of less than $0.5 \%$ in the DSR at the surface, when the surface albedo varied by $\pm 10 \%$ from its value. Maximum differences do not exceed $1.5 \%$.

From Fig. 2 it is obvious that Terra and Aqua MODIS data are in general agreement, showing an important spectral variation of surface albedo at the visible and near-IR ranges. A seasonal variation is also apparent, with higher values in the range $0.9-1.4 \mu \mathrm{m}$, during summer. The spectral behavior is 


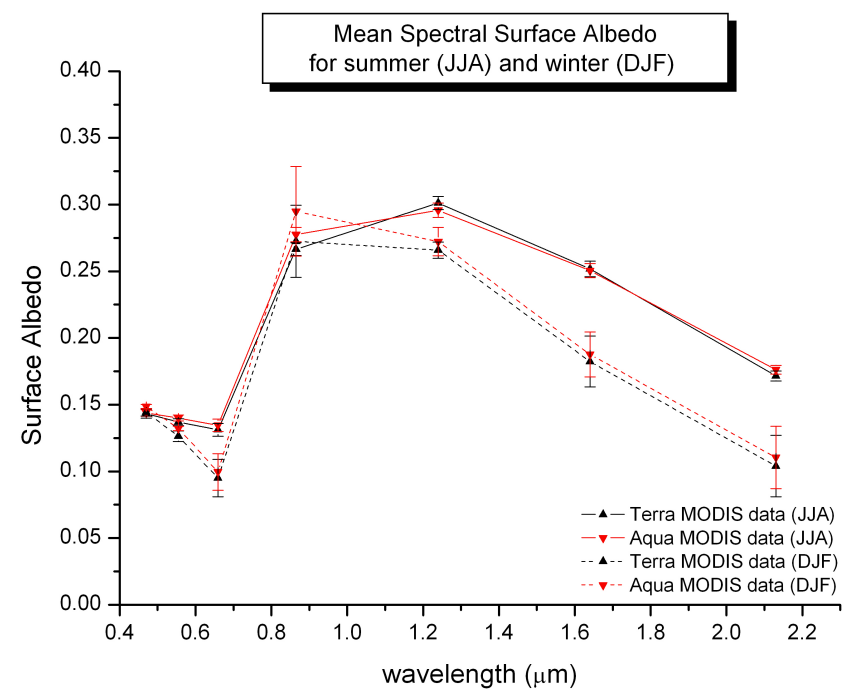

Fig. 2. Mean land-surface albedo at 7 wavelengths, derived from Terra and Aqua MODIS instruments, for the summer (JJA) and winter (DJF) months of the 9-year period 2000-2008, at the HCMR station in Crete. Error bars represent the standard deviation for each wavelength.

in very good agreement with the surface reflectivity for vegetation (the station area is surrounded mainly by vegetation), as given in Vardavas and Taylor (2011). The annual vegetation cycle can also explain the observed seasonal variation, as bare soil during the summer months has a higher nearinfrared reflectivity than vegetation cover during winter (see Fig. 10.8, Vardavas and Taylor, 2011, p. 359).

\subsection{Clouds}

All cloud data listed in Table 1, except for the cloud physical thickness, are available from MODIS. The cloud physical thickness was taken from Peng et al. (1982), who give the parameter for different cloud types, depending on latitude, as explained in Hatzianastassiou and Vardavas (1999). In the present work, we use the ISCCP cloud classification scheme (three cloud types: low, middle and high), adjusted to MODIS data. According to this scheme, cloud data are classified depending on the cloud-top pressure: low-level clouds have top pressures greater than or equal to $680 \mathrm{mbar}$, highlevel cloud-top pressures are less than 440 mbar and middlelevel cloud-top pressures lie between 440 and 680 mbar. Specifically, we use the $5 \times 5 \mathrm{~km}$ MODIS cloud data pixel covering the station to make the classification and so obtain the cloud properties from the MODIS data.

MODIS provides cloud scattering optical depth, $\tau_{\mathrm{c}}^{\mathrm{s}}$ for the wavelengths $0.65 \mu \mathrm{m}$ over land and $0.86 \mu \mathrm{m}$ over oceans. For the computation of the cloud shortwave transmissivity and reflectivity in the near-IR, a radiation transfer model also requires cloud absorption as well as scattering optical depth. These were derived from the $\tau_{\mathrm{c}}^{\mathrm{s}}$ values given by MODIS, based on Mie computations as described in Hatzianastassiou et al. (2004a) for both liquid and ice clouds. For the UVvisible range, $\mathrm{g}_{\mathrm{c}}$ is set equal to 0.85 and 0.78 for liquid and ice clouds respectively, while for the near-IR the corresponding values are 0.82 and 0.80 (Hatzianastassiou et al., 2004a).

\subsection{Aerosols}

The model requires instantaneous aerosol optical properties, namely AOT, single scattering albedo $\left(\omega_{\text {aer }}\right)$ and asymmetry parameter $\left(\mathrm{g}_{\mathrm{aer}}\right)$. Data of AOT and $\mathrm{g}_{\mathrm{aer}}$ are provided by MODIS at 7 wavelengths, from 0.47 to $2.13 \mu \mathrm{m}$. Data of $\omega_{\text {aer }}$ are provided by the FORTH-CRETE AERONET station at 4 wavelengths, from 0.44 to $1.02 \mu \mathrm{m}$ (see Sect. 2). According to Dubovik et al. (2000), the error in $\omega_{\text {aer }}$ retrieval can range between 0.03 and 0.07 , depending primarily on the aerosol optical depth, the aerosol type and the range of the solar almucantar used in the retrieval procedure. High optical depth values and full solar almucantar minimize the $\omega_{\text {aer }}$ error. These criteria are applied for the retrieval of AERONET Level $2.0 \omega_{\text {aer }}$. Due to the lack of sufficient measurements from the AERONET station during winter months (November-February), $\omega_{\text {aer }}$ was obtained by interpolating values from autumn and spring months.

The spectral model computations are performed for specific wavelengths and spectral intervals for the UV-visible and near-IR regions. Thus, the required AOT, $\omega_{\text {aer }}$ and $g_{\text {aer }}$ for these wavelengths and intervals are obtained through interpolation and extrapolation. For the $0.20-0.47 \mu \mathrm{m}$ region, linear extrapolation is used for $\omega_{\mathrm{aer}}$ and $\mathrm{g}_{\mathrm{aer}}$ and exponential extrapolation for AOT, based on comparisons with corresponding data from AERONET and GADS data base, as well as AOT data in the UV-A and UV-B regions from Thessaloniki meteorological station. In the $2.13-10 \mu \mathrm{m}$ region, linear extrapolation is used for all three parameters. The sensitivity analysis performed for all aerosol data shows that variations of the order of $\pm 10 \%$ from this approach do not alter significantly our model results, as discussed in Section 4.2. Finally, the radiative fluxes are computed for each wavelength and spectral interval, with and without aerosols, which are then summed to yield the total SW fluxes, and from their difference the DRE of aerosols.

\section{Results}

\subsection{MODIS Aerosol data validation}

Aerosol data available from MODIS (namely AOT, fine mode AOT and g), have been validated against measurements from FORTH-CRETE AERONET station, collocated in space and time. MODIS Aerosol algorithm retrieves AOT at 0.47 and $0.66 \mu \mathrm{m}$ wavelengths (and interpolates at $0.55 \mu \mathrm{m})$ over land surfaces and at seven spectral wavelengths $(0.47,0.55,0.66,0.87,1.2,1.6,2.1 \mu \mathrm{m})$ over oceans 
(Kaufman et al., 1997; Tanré et al., 1997). For the comparison database we use AERONET Level 2 data from FORTHCRETE AERONET station, which are both cloud screened and quality assured (Holben et al., 1998; Dubovik and King, 2000; Dubovik et al., 2000). The AERONET station gives AOT at $0.44,0.50,0.67,870$ and $1.02 \mu \mathrm{m}$, from direct solar radiation measurements (Holben et al., 2001).

The MODIS Level 2 aerosol products are data sets with a pixel size of $10 \mathrm{~km} \times 10 \mathrm{~km}$ at nadir. AERONET AOT data are acquired at $15 \mathrm{~min}$ intervals on the average. To achieve a meaningful and balanced validation, we compare spatial statistics from MODIS with corresponding temporal statistics from AERONET (Ichoku et al., 2002). The justification is that, since air masses are constantly in motion, an air mass captured by MODIS across a certain horizontal span over the AERONET site, will be sampled by the sunphotometer during a certain time period.

The basis for the procedure is to identify within each MODIS aerosol image the pixel falling over the station (validation point) by its longitude and latitude. Then an NxN $\mathrm{km}$ subset centered on that pixel is extracted and its mean $\left(\mu_{\mathrm{s}}\right)$ and standard deviation $\left(\sigma_{\mathrm{s}}\right)$ are computed, where $\mu_{\mathrm{s}}$ represents the average value of the parameter, while $\sigma_{\mathrm{s}}$ expresses its local spatial variability. We tested three window sizes $(30 \times 30,50 \times 50$ and $70 \times 70 \mathrm{~km})$ and found that the window-size dependence is generally small and has no specific trend, at least for the window-size range tested. However, we use $50 \times 50 \mathrm{~km}$ window-size for calculating all validation spatial statistics, as it is generally adopted and used internationally (Ichoku et al., 2002). For the location of the station identified in the MODIS data, the AERONET sunphotometer data acquired during the $1 \mathrm{~h}$ period centered on the MODIS overpass time ( \pm half hour) are extracted. Statistics of the sunphotometer data subsets (mean and standard deviation) are computed. We consider only data subsets computed from a certain minimum number of values (5 pixels out of 25 for MODIS and 2 data points for AERONET). We use the aerosol properties derived from MODIS ocean algorithm, as suggested by Remer et al. (2002), for coastal and island stations.

For the validation of AOT, we use values at 675 and $870 \mathrm{~nm}$ from FORTH-CRETE AERONET station and at 660 and $865 \mathrm{~nm}$ from MODIS Terra and Aqua. These channels are sufficiently similar for direct comparison.

In Fig. 3, the mean values of the $50 \times 50 \mathrm{~km}$ MODIS subset and the \pm 30 min temporal average of the corresponding AERONET timeseries are plotted. The error bars represent the respective spatial and temporal standard deviations. The red line is the linear regression fit, with the equation, determination coefficient and number of points used shown at the lower right corner. The agreement, as represented by the linear fit, is within the expected uncertainty of the MODIS retrieval algorithm over ocean $(\Delta \tau= \pm 0.03 \pm 0.05 \tau)$ for small values of AOT, as denoted by the dotted lines in the figures. The slight overestimation of AOD by MODIS might
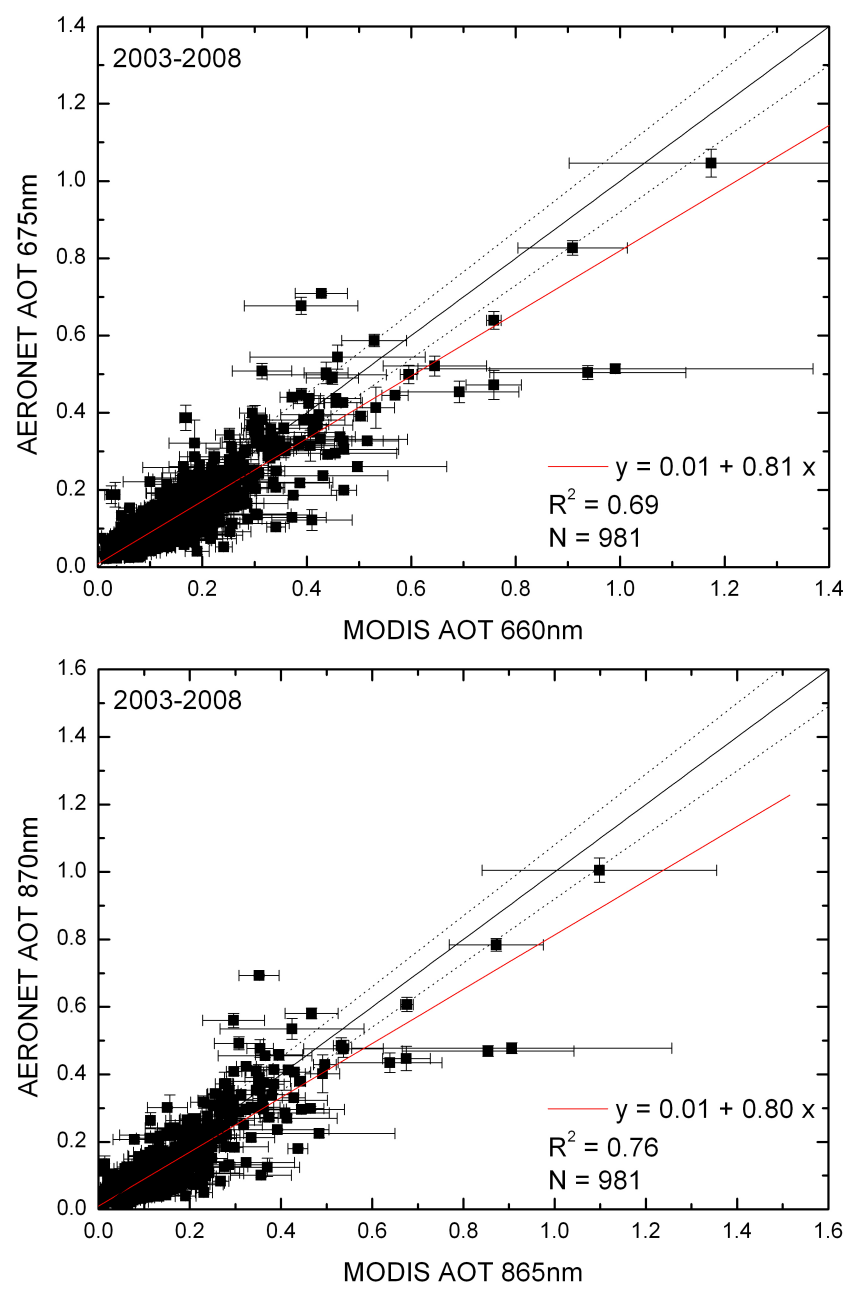

Fig. 3. Scatter plots of means of AOT $(660 \mathrm{~nm}$ (a) and $865 \mathrm{~nm}$ (b)) of MODIS $50 \times 50 \mathrm{~km}$ subsets against AOT $(675 \mathrm{~nm}$ (a) and 870nm (b)) of AERONET $1 \mathrm{~h}$ subsets for the period 2003-2008. The error bars represent the respective standard deviations. The red line is the linear regression fit, with the equation, determination coefficient and number of points used shown at the lower right corner. The dotted lines correspond to the expected uncertainty of the MODIS retrieval algorithm.

be partly explained by the slightly smaller observation wavelengths of MODIS than of AERONET. Similar results were obtained by Remer et al. (2002), Ichoku et al. (2002) and Chu et al. (2002), although these studies involved data from several AERONET stations.

The same validation procedure has been used for the cases of fine mode AOT and $\mathrm{g}$. Fine mode AOT validation was performed for the 0.47 and $0.50 \mu \mathrm{m}$ wavelengths of MODIS and AERONET, respectively. The two data sets are not well correlated, with the determination coefficient being 0.38 and the slope equal to 0.59 . These results show that MODIS tends to overestimate the fine mode AOT, as was shown by similar studies for dust-dominated aerosols (Santese et al., 2007; 
Kleidman et al., 2005). The MODIS asymmetry parameter was validated against the corresponding AERONET product at the two pairs of wavelengths used in the case of the total AOT validation. While the two products are not well correlated at the 660 and $675 \mathrm{~nm}$ wavelengths $\left(R^{2}=0.39\right.$, slope $=0.59)$, the correlation is improved at the $865-870 \mathrm{~nm}$ wavelengths $\left(R^{2}=0.51\right.$, slope $\left.=0.82\right)$. Nevertheless, the narrow value range of the asymmetry parameter and the sensitivity test we performed for both these parameters, suggest that the uncertainties associated with the MODIS product do not affect significantly our results.

\subsection{Model DSR validation against HCMR and Finokalia station measurements and sensitivity analysis}

Aerosol DRE cannot be directly validated against measurements. This can be only indirectly and partly achieved, through validation of DRE components $\left(F, F_{\text {no-aerosol }}\right)$ and especially of $F$ via comparison against real surface measurements of solar radiation. Surface measurement data were obtained from both HCMR and Finokalia meteorological stations. At HCMR, a CM11 pyranometer is used, with spectral range $310-2800 \mathrm{~nm}$ and $2 \%$ uncertainty, while at Finokalia a CM3 pyranometer is installed with spectral range 305$2800 \mathrm{~nm}$ and $10 \%$ uncertainty. Both pyranometers have flat spectral sensitivities. Figure 4 shows the model results of the instantaneous DSR at HCMR (FORTH-CRETE AERONET) station, against corresponding measurements from the station (collocated in a \pm 15 min interval), for the period 2003-2008, when both station and MODIS data are available. The model was run separately with MODIS Terra (Fig. 4a) and Aqua (Fig. 4b) data as input. The model DSR in both cases is in very good agreement with the ground measurements, as can be seen from the regression fit and the determination coefficients. Nevertheless, there is a bias of -72 and $-52 \mathrm{Wm}^{-2}$, which corresponds to $8.8 \%$ and $6.5 \%$ of the mean DSR values found, using Terra and Aqua MODIS data, respectively. This trend shows that the model tends to overestimate the DSR at the surface. Figure 5 shows the corresponding results for the DSR at Finokalia station. In this case, the bias is lower $\left(-35\right.$ and $-38 \mathrm{Wm}^{-2}$ ), corresponding to $4.3 \%$ and $4.6 \%$ of the mean output DSR, using Terra and Aqua MODIS input, respectively. The validation of the model DSR against the AERONET station has confirmed the tendency of the model to overestimate the DSR at the surface. The two data sets were well correlated $\left(R^{2}=0.77\right)$, similarly to the validation against HCMR and Finokalia stations.

To investigate the sensitivity of the model to the uncertainty of MODIS AOTs, in the case of the HCMR station, we recalculated the DSR, using AOT values computed from the error limits of the MODIS retrieval algorithm $(\tau \pm \Delta \tau)$. The two new output datasets were then subtracted from the original model DSR output. Figures $6 a$ and $b$ show the differences in the estimated DSR, when we use the error limits
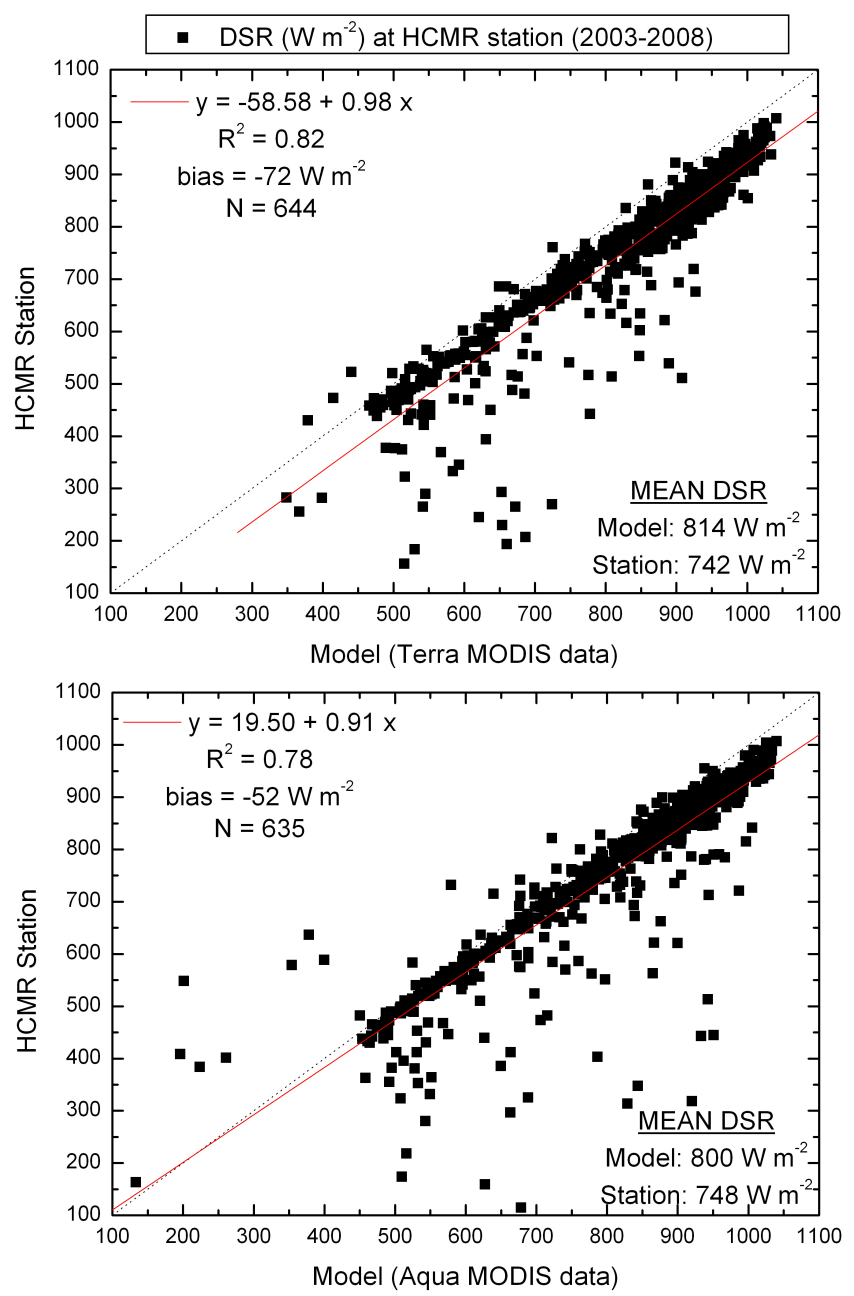

Fig. 4. Scatter plots of the model instantaneous DSR using MODIS Terra (a) and Aqua (b) data, against corresponding ground measurements from the HCMR station, for the years 2003-2008. The lines are the linear regression fits, with the equations, determination coefficients, biases, number of points and mean DSR values shown.

of MODIS AOT retrieval algorithm instead of the AOT values, for Terra and Aqua MODIS respectively. These differences range between almost $0.5 \%$ during summer and $1.5 \%$ in winter, when due to overcast conditions, they lead either to significantly small AOTs or missing AOT retrievals from MODIS algorithm.

Sensitivity tests have also been performed for fine mode AOT, $g$ and $\omega$. In all these tests, the parameter under consideration was allowed to vary in the range $\pm 10 \%$ from the original value, and the model output surface DSR was compared against its corresponding original value. The differences in DSR due to fine mode AOT variation were lower compared to those due to the total AOT (mean $\sim 0.25 \%$, reaching up to $1 \%$ in extreme cases), probably due to the lower fine mode AOT values. The asymmetry factor $\pm 10 \%$ variation caused a variation in the surface DSR of the order 

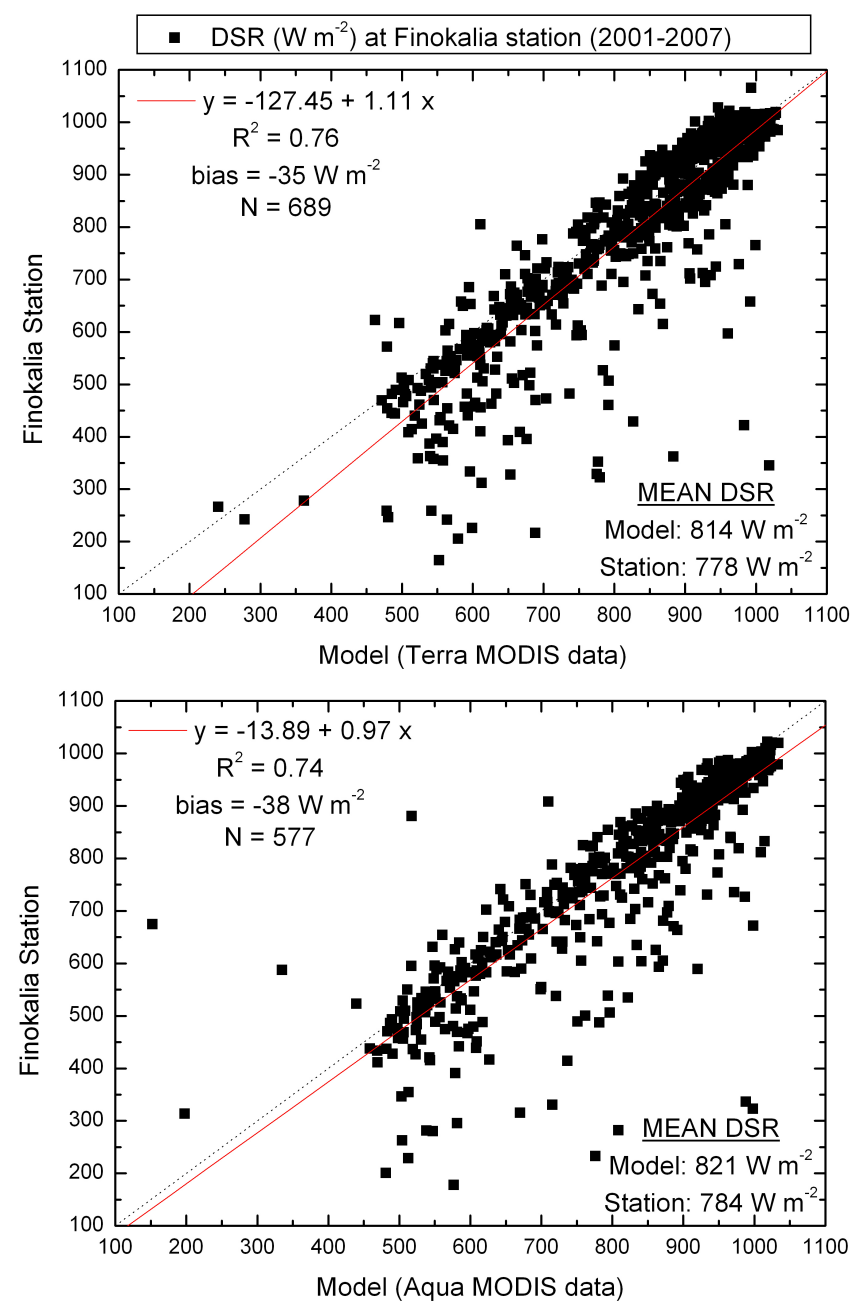

Fig. 5. Scatter plots of the model instantaneous DSR using MODIS Terra (a) and Aqua (b) data, against corresponding ground measurements from the Finokalia station, for the years 2001-2007. The lines are the linear regression fits, with the equations, determination coefficients, biases, number of points and mean DSR values shown.

of $0.6-0.7 \%$, with a small number of maximum differences ranging between 1.5 and $2.5 \%$. This result, along with the small range of values of $g(0.60-0.75)$, suggests that the use of MODIS $g$ data does not affect the validity of the model outputs. Single scattering albedo variations by $+10 \%$ or $-10 \%$ cause different results in the corresponding surface DSR outputs. In the case of $+10 \%$ change in $\omega$ values, the output DSR increases by $2 \%$ and $1.9 \%$ on average, for MODIS Aqua and Terra, respectively. When reduced by $10 \%, \omega$ causes a decrease in surface DSR by $2.8 \%$ and $2.6 \%$. Nevertheless, the smaller seasonal variation of $\omega$ and the uncertainties regarding its retrieval, as described in Dubovik et al. (2000), suggest that possible variations of $\omega$ never reach values of $10 \%$.
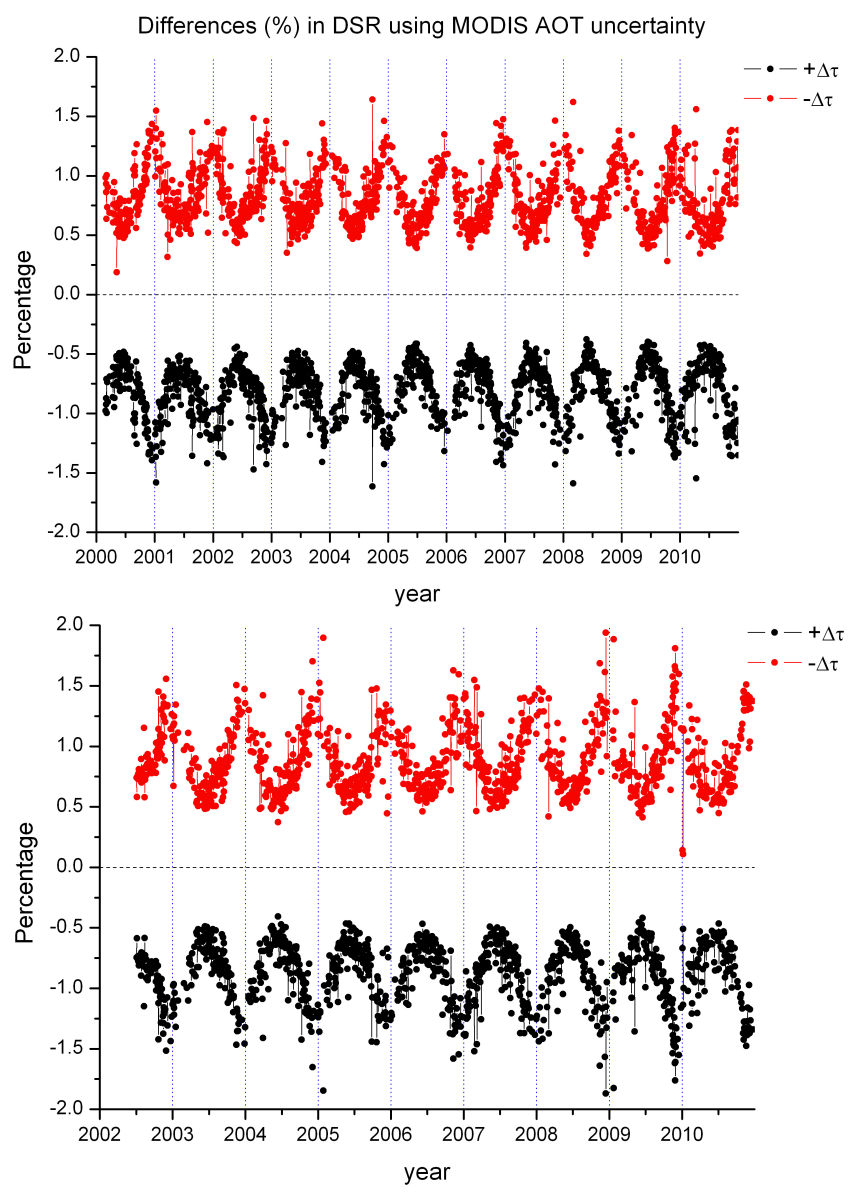

Fig. 6. Timeseries of the differences in model instantaneous DSR $\left(\mathrm{Wm}^{-2}\right)$, using Terra (a) and Aqua (b) MODIS AOT data and the error limits of the AOT retrieval algorithm $(\tau \pm \Delta \tau)$, above the HCMR station, for the years 2000-2010.

\subsection{Time series of instantaneous aerosol DRE: Study of dust events}

Figures 7 and 8 show the instantaneous $\mathrm{SW}$ aerosol $\Delta \mathrm{F}$ at the surface $\left(\Delta \mathrm{F}_{\text {Surface }}\right)$, the net surface (surface absorption, $\left.\Delta \mathrm{F}_{\text {NetSurface }}\right)$, within the atmosphere $\left(\Delta \mathrm{F}_{\mathrm{AtmAb}}\right)$ and at TOA $\left(\Delta \mathrm{F}_{\mathrm{TOA}}\right)$, for the corresponding years of available MODIS data over the HCMR station. The results show that at this site, aerosols cool the Earth-Atmosphere system, by reflecting radiation back to space. They also cool the Earth's surface, while they cause a warming effect within the atmosphere. Aerosols increase multiple scattering within the atmosphere and together with their own absorption increase the probability of photon absorption within the atmosphere, leading to a warming effect. The aerosol DRE generally takes higher values in summer, due to the larger incoming solar radiation and the clear-sky conditions prevailing during this season. Instantaneous values of DRE for the period 2000-2010, calculated from both output data sets (Aqua and 

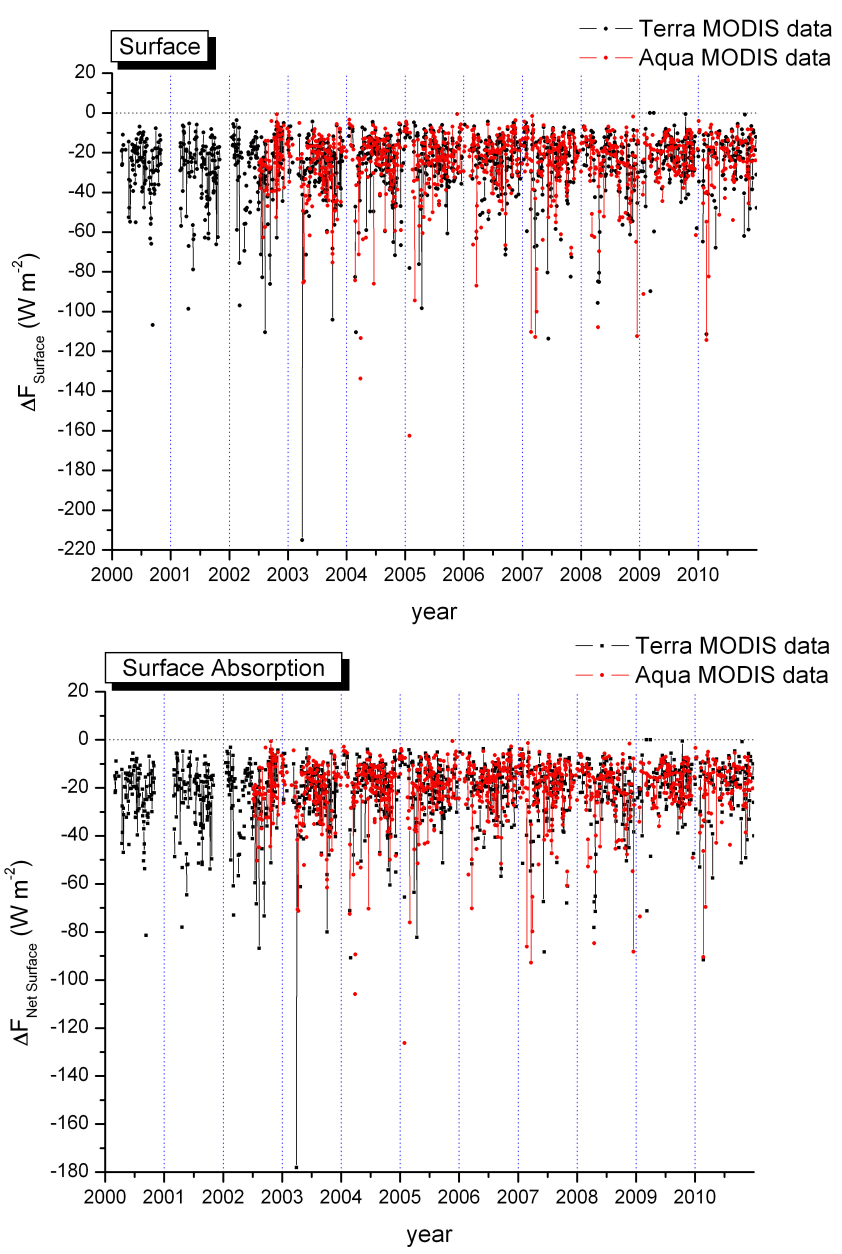

Fig. 7. Time series of the instantaneous aerosol effect at the surface (incident (a) and absorbed (b) radiation), as computed from the model, based on MODIS Level 2 Terra and Aqua data, for the period 2000-2010, at the HCMR station, Crete.

Terra MODIS), are given in Table 2. The model DREs at the surface and at TOA are compared with the corresponding values available from the FORTH-CRETE AERONET station. The model output is well correlated with the AERONET output in the case of TOA DRE $\left(R^{2}=0.67\right.$, slope $\left.=1.06\right)$. At the surface, the correlation is fair $\left(R^{2}=0.50\right.$, slope $\left.=0.64\right)$, while the model tends to overestimate the surface DRE for small absolute values (less than $-10 \mathrm{Wm}^{-2}$ ).

Dust events, associated with coarse particles transported from African deserts, enhance significantly the aerosol DRE, especially at the surface and within the atmosphere. To further investigate dust events, we first defined them according to the following criteria: the AOT value should be greater than the mean AOT value for the whole period plus one standard deviation, and the Angstrom exponent less than the corresponding mean value for the whole period minus one standard deviation. Applying the above criteria to both Aqua and Terra MODIS (AOT at $865 \mathrm{~nm}$ and Angstrom exponent
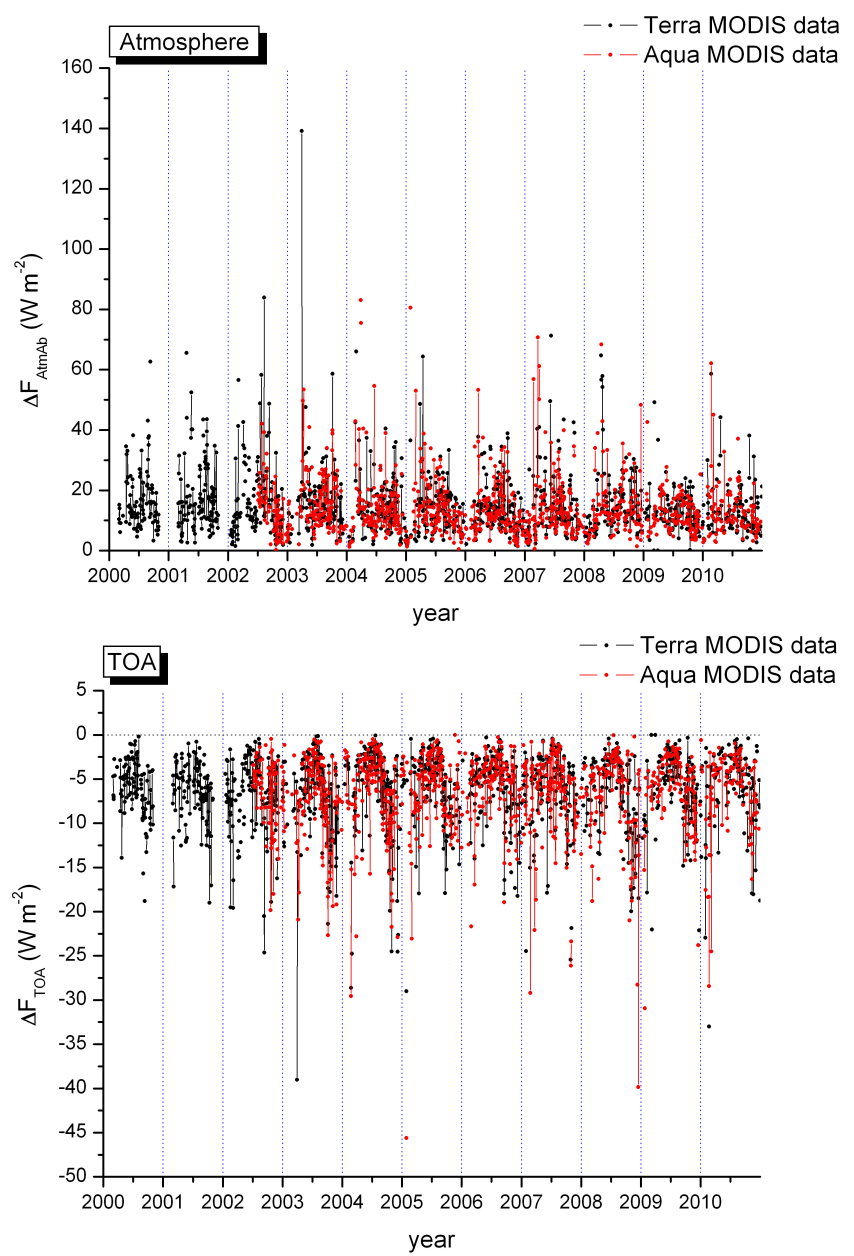

Fig. 8. Time series of the instantaneous aerosol effect in the atmosphere (a) and at TOA (b), as computed from the model, based on MODIS Level 2 Terra and Aqua data, for the period 2000-2010, at the HCMR station, Crete.

Table 2. Mean instantaneous values with standard deviations of DRE for the period 2000-2010, calculated from both output data sets (Aqua and Terra MODIS).

\begin{tabular}{lc}
\hline & DRE $\left(\mathrm{Wm}^{-2}\right)$ \\
\hline Surface & $-26 \pm 16$ \\
Surface Absorption & $-21 \pm 13$ \\
Atmospheric Absorption & $15 \pm 10$ \\
TOA & $-6 \pm 5$ \\
\hline
\end{tabular}

at $550-860 \mathrm{~nm}$ ) and AERONET data (AOT at $1020 \mathrm{~nm}$ and Angstrom exponent at $440-870 \mathrm{~nm}$ ), we found several cases when dust events occurred. These cases were further confirmed through back-trajectories. Back-trajectory calculations were made using the HYSPLIT_4 (Hybrid SingleParticle Lagrangian Integrated Trajectory) modeling system. 
This public domain model (http://www.arl.noaa.gov/ready/ hysplit4.html) is documented in the international literature (Draxler and Hess, 1998). Some of the dust event cases are shown in Table 3, along with the corresponding DRE and aerosol properties. Missing values are due to lack of model input data.

Mean values and standard deviations of the aerosol parameters (AOT, Angstrom exponent, g and $\omega$ ) were calculated for the entire time series and the dust event days separately. The mean AOT at $0.55 \mu \mathrm{m}$ for the whole period examined was $0.21 \pm 0.19$, while during dust events it increased to $0.72 \pm 0.66$, exceeding 4.0 in some extreme cases. Values of AOT $>1.0$ during dust episodes have been reported in the past (e.g. Kaskaoutis et al., 2008; Tafuro et al., 2006). The asymmetry parameter at the same wavelength shows smaller variability, with values $0.71 \pm 0.04$ and $0.75 \pm 0.02$, respectively, reaching up to 0.78 . Small variability was also found in the case of $\omega$ at $0.67 \mu \mathrm{m}: 0.95 \pm 0.02$ and $0.96 \pm 0.01$ for the entire period and dust events, respectively. It should be mentioned that during dust episodes, the availability of $\omega$ data from the AERONET station was limited, with only 23 values found for the whole period examined. During dust events, the Angstrom exponent decreased from $0.83 \pm 0.42$ for the entire period to $0.25 \pm 0.12$, as expected for dust particles with large radius. Similar values during dust outbreaks in Greece and the Central Mediterranean were reported by Kaskaoutis et al. (2008); Gómez-Amo et al. (2011) and Tafuro et al. (2006).

During these events, the decrease of the instantaneous surface downwelling radiation can range between -80 and $-200 \mathrm{Wm}^{-2}$ and the corresponding decrease in surface absorption between -60 and $-180 \mathrm{Wm}^{-2}$, while the warming effect within the atmosphere ranges between 60 and $140 \mathrm{Wm}^{-2}$. The outgoing radiation at TOA can be increased by 25 to $45 \mathrm{Wm}^{-2}$. Similar results have been reported by Mallet et al. (2009), in a study of a dust event over West Africa. The maximum instantaneous DRE values, estimated by numerical simulations, were -172 and $-26 \mathrm{Wm}^{-2}$ at the surface and at TOA, respectively. Gómez-Amo et al. (2011) also reported very high maximum DRE values during a 2007 Saharan dust event in the central Mediterranean: $-224 \mathrm{Wm}^{-2}$ at the surface and $-19 \mathrm{Wm}^{-2}$ at TOA. Haywood et al. (2003) found similar results, studying a Saharan dust episode over Cape Verde: the surface DRE of dust was shown to reach instantaneous values of approximately $-130 \mathrm{Wm}^{-2}$.

\subsection{Mean monthly time series and trends}

To investigate the seasonal characteristics and possible trends of the aerosol DRE during the period examined, we calculated the monthly mean values from the instantaneous values. In this analysis, monthly mean values can be regarded as representative of the overpass time interval of each satellite. The results of the monthly mean DRE at the surface

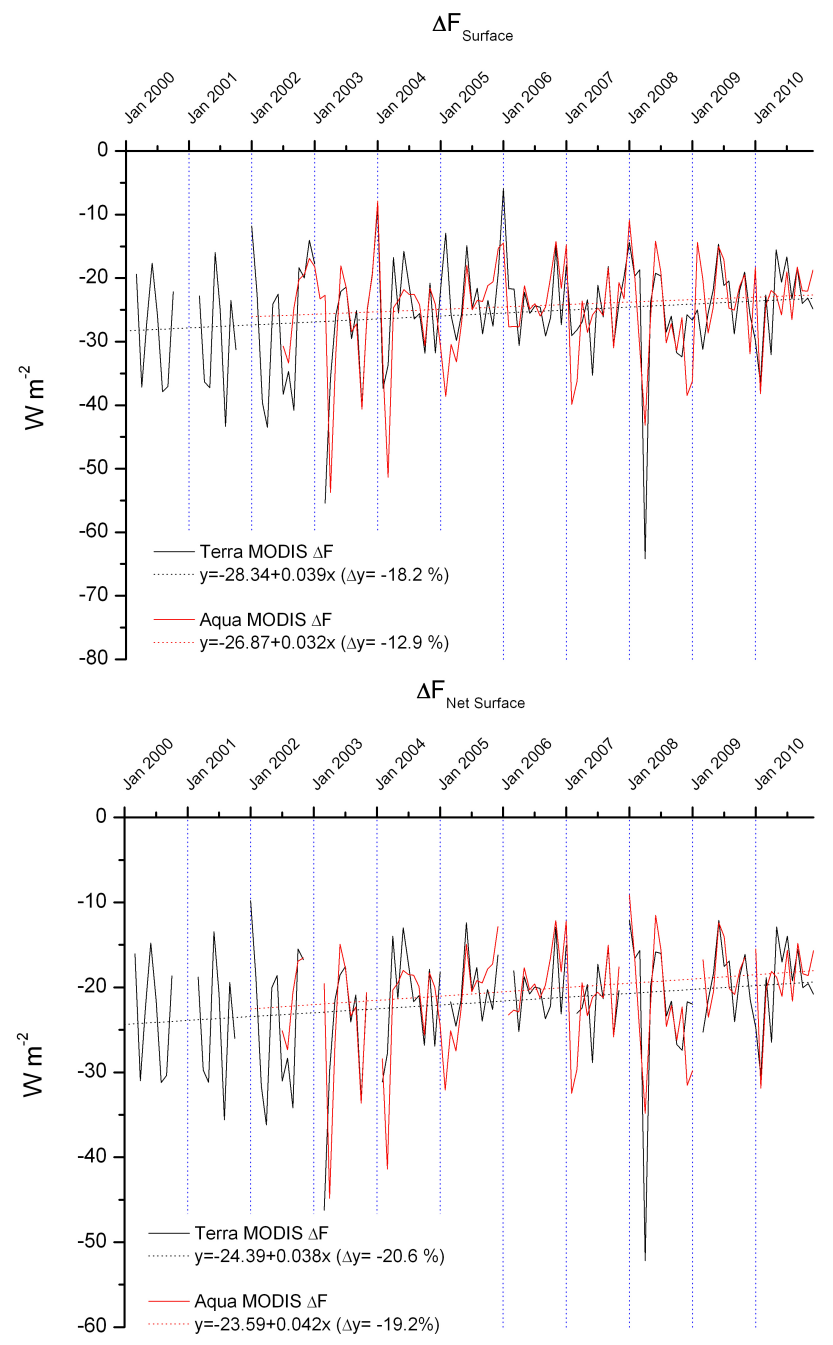

Fig. 9. Time series of the monthly mean aerosol DRE at the surface (incident (a) and absorbed (b) radiation), as computed from the model, based on Terra and Aqua MODIS Level 2 data, for the period 2000-2010, at the HCMR station, Crete. The applied linear fits to the time series are also shown (dotted lines).

(DSR and surface absorption), within the atmosphere and at TOA, are shown in Figs. 9 and 10. Monthly mean DREs that were computed from less than 5 daily mean values are not included in this analysis, to assure that average values are representative for each month. From Fig. 9a it is obvious that the mean monthly aerosol DRE on the DSR can reach up to $-60 \mathrm{Wm}^{-2}$, while typical values range between -15 and $-35 \mathrm{Wm}^{-2}$. The corresponding monthly mean peak values for the DRE on the radiation absorbed by the surface (Fig. 9b) are -40 to $-50 \mathrm{Wm}^{-2}$, with a typical range of -15 to $-30 \mathrm{Wm}^{-2}$. The DRE increases the radiation absorbed by the atmosphere (Fig. 10a) by 10 to $20 \mathrm{Wm}^{-2}$, but can reach up to $40 \mathrm{Wm}^{-2}$. At TOA, the result of the DRE is an increase in the outgoing radiation, thus decreasing the net TOA incoming radiation by -4 to $-12 \mathrm{Wm}^{-2}$ 
Table 3. Characteristic dates of dust events and corresponding DRE $\left(\mathrm{Wm}^{-2}\right)$ at the surface, within the atmosphere, at TOA and net surface, AOT and $\mathrm{g}$ at $550 \mathrm{~nm}, \omega$ at $670 \mathrm{~nm}$ and Angstrom coefficient.

\begin{tabular}{|c|c|c|c|c|c|c|c|c|c|c|c|c|c|c|c|c|}
\hline $\begin{array}{l}\text { DRE } \\
\left(\mathrm{Wm}^{-2}\right) \\
\text { Dates }\end{array}$ & \multicolumn{2}{|c|}{$\begin{array}{l}\text { Surface } \\
\text { Terra Aqua }\end{array}$} & \multicolumn{2}{|c|}{$\begin{array}{l}\text { Atmosphere } \\
\text { Terra Aqua }\end{array}$} & \multicolumn{2}{|c|}{$\begin{array}{l}\text { TOA } \\
\text { Terra Aqua }\end{array}$} & \multicolumn{2}{|c|}{$\begin{array}{l}\text { NetSurface } \\
\text { Terra Aqua }\end{array}$} & \multicolumn{2}{|c|}{$\begin{array}{l}\mathrm{AOT}_{550 \mathrm{~nm}} \\
\text { Terra Aqua }\end{array}$} & \multicolumn{2}{|c|}{$\begin{array}{l}\mathrm{g}_{550 \mathrm{~nm}} \\
\text { Terra Aqua }\end{array}$} & \multicolumn{2}{|c|}{$\begin{array}{l}\omega_{670 \mathrm{~nm}} \\
\text { Terra Aqua }\end{array}$} & \multicolumn{2}{|c|}{$\begin{array}{l}\AA \\
\text { Terra Aqua }\end{array}$} \\
\hline $29 / 03 / 2003$ & -215 & & 139 & & -39 & & -178 & & 1.70 & & 0.75 & & 0.95 & & 0.16 & \\
\hline $28 / 02 / 2004$ & -110 & & 66 & & -25 & & -91 & & 0.80 & & 0.77 & & 0.95 & & 0.13 & \\
\hline $27 / 03 / 2004$ & & -134 & & 83 & & -23 & & -106 & & 0.94 & & 0.73 & & 0.95 & & 0.50 \\
\hline $29 / 03 / 2004$ & & -113 & & 75 & & -14 & & -89 & & 0.87 & & 0.75 & & 0.95 & & 0.43 \\
\hline $18 / 06 / 2004$ & & -86 & & 55 & & -16 & & -70 & & 0.82 & & 0.74 & & 0.96 & & 0.44 \\
\hline $26 / 01 / 2005$ & -78 & -163 & 37 & 81 & -29 & -46 & -66 & -126 & 0.49 & 1.14 & 0.75 & 0.77 & 0.95 & 0.95 & 0.12 & 0.55 \\
\hline $28 / 02 / 2005$ & & -94 & & 53 & & -23 & & -76 & & 0.65 & & 0.75 & & 0.95 & & 0.10 \\
\hline $12 / 04 / 2005$ & -98 & & 64 & & -18 & & -82 & & 0.77 & & 0.76 & & 0.95 & & 0.30 & \\
\hline $26 / 02 / 2006$ & & -66 & & 34 & & -22 & & -56 & & 0.44 & & 0.74 & & 0.95 & & 0.48 \\
\hline $10 / 06 / 2007$ & -114 & -53 & 71 & 36 & -17 & -6 & -88 & -42 & 1.06 & 0.51 & 0.75 & 0.76 & 0.96 & 0.96 & 0.26 & 0.14 \\
\hline $02 / 11 / 2007$ & -73 & & 39 & & -22 & & -61 & & 0.49 & & 0.75 & & 0.94 & & 0.41 & \\
\hline
\end{tabular}
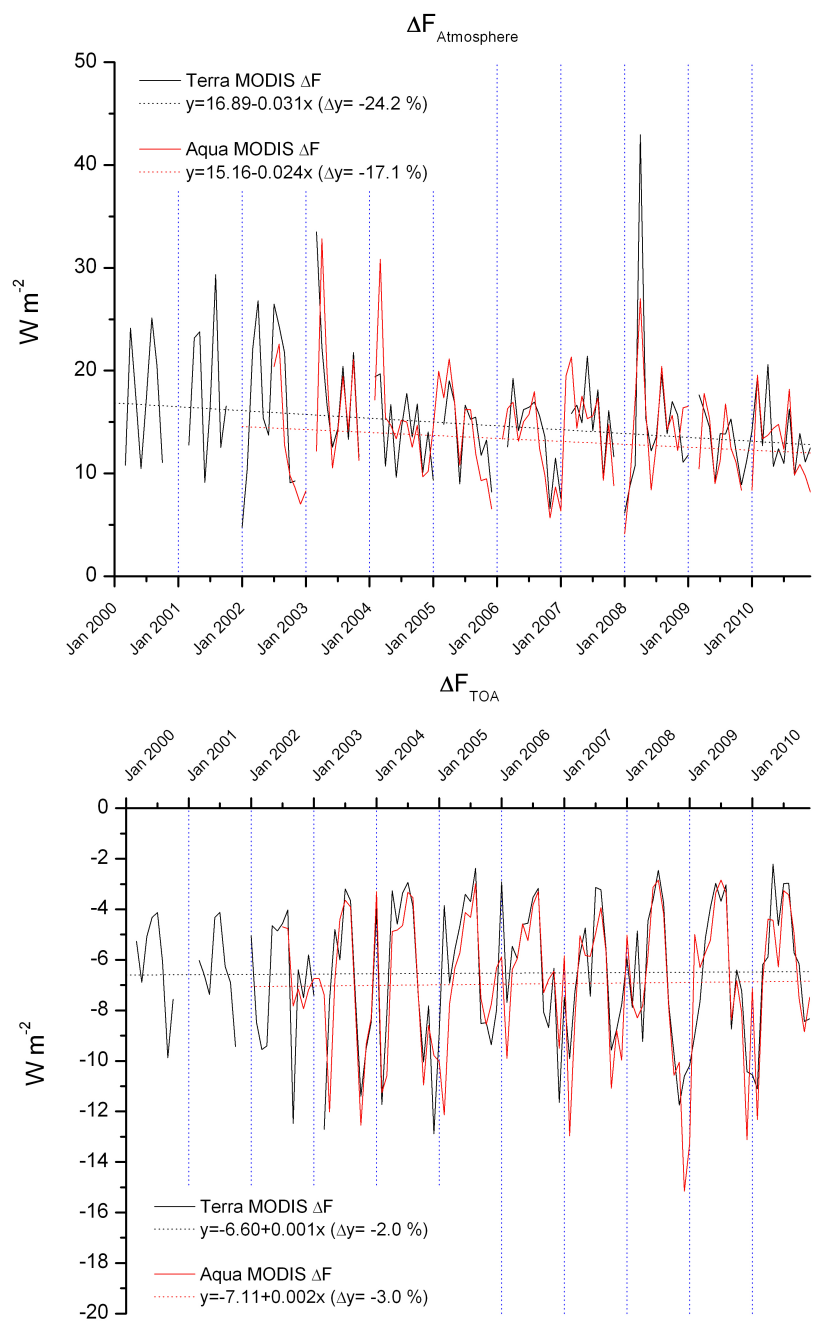

Fig. 10. As in Fig. 9, but for the aerosol DRE within the atmosphere (a) and at TOA (b).
(Fig. 10b). The applied linear regression fits to both time series (from MODIS Terra and Aqua), are also given, along with the computed changes in the DRE $(\Delta y=\Delta(\mathrm{DRE}))$, over the period covered from each satellite.

The results of Figs. 9 and 10 also show that almost every year there are two maxima in DRE, one occurring in spring (mainly April) and the other in late summer (AugustSeptember). This behavior is associated with the corresponding seasonal variation of AOT, which presents high values during these months, due to strong dust episodes taking place in spring and high anthropogenic aerosol load in summer, as was shown by Fotiadi et al., (2006). Table 4 presents the monthly mean AOT values and the corresponding standard deviations from Terra and Aqua MODIS, calculated over the period examined. The results verify this seasonal behavior. This behavior is also obvious if we perform the same trend analysis for the MODIS derived AOT at $0.55 \mu \mathrm{m}$, as shown in Fig. 11. The applied linear fit to the time series of AOT and DRE show that there is a decreasing trend from 2000 to 2010. In order to perform a robust trend analysis, we took the deseasonalised time series, normalized by the standard deviation, as explained in Matsoukas et al. (2011). Fitting linear trends to the normalized time series, we found that $\Delta F_{\text {Surface, }}$, $\Delta \mathrm{F}_{\text {NetSurface }}$ and $\Delta \mathrm{F}_{\mathrm{TOA}}$ using Terra MODIS data, along with $\Delta \mathrm{F}_{\text {NetSurface }}$ and $\Delta \mathrm{F}_{\mathrm{Atm} A b}$ using Aqua MODIS data, have trends statistically significant at the $95 \%$ confidence level. This trend is in general agreement with the results presented by Papadimas et al. (2008), which showed that there is a decreasing trend in AOT values over the Mediterranean basin, using MODIS Level 3 data and examining the period from 2000 to 2006.

\subsection{Contribution of anthropogenic and natural aerosols on DRE}

The separation of total aerosol DRE into its natural and anthropogenic components is essential and very important in view of assessing human effects, through emissions of particulate matter (which may also influence natural aerosol 


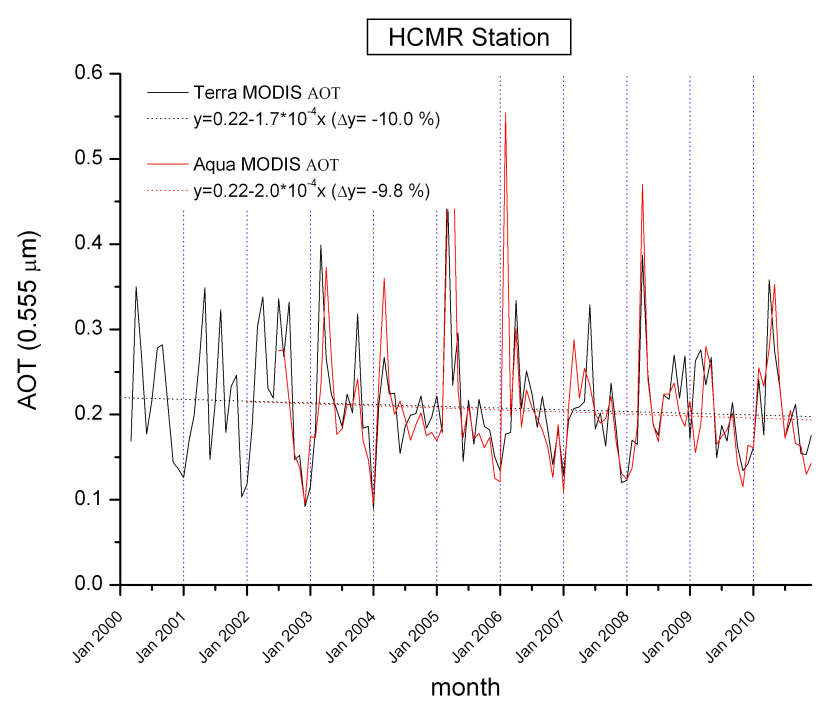

Fig. 11. Time series of the monthly mean AOT at $0.555 \mu \mathrm{m}$, based on MODIS Level 2 Terra and Aqua data, for the period 2000-2010, at the HCMR station, Crete. The applied linear fits to the time series are also shown (dotted lines).

Table 4. Monthly mean AOT and standard deviation from Terra and Aqua MODIS, calculated for the period 2000-2010.

\begin{tabular}{lcc}
\hline Month & Terra MODIS AOT & Aqua MODIS AOT \\
\hline January & $0.14 \pm 0.13$ & $0.15 \pm 0.14$ \\
February & $0.20 \pm 0.14$ & $0.23 \pm 0.42$ \\
March & $0.25 \pm 0.40$ & $0.27 \pm 0.40$ \\
April & $0.29 \pm 0.18$ & $0.33 \pm 0.44$ \\
May & $0.26 \pm 0.16$ & $0.25 \pm 0.17$ \\
June & $0.20 \pm 0.12$ & $0.20 \pm 0.11$ \\
July & $0.21 \pm 0.09$ & $0.20 \pm 0.08$ \\
August & $0.22 \pm 0.10$ & $0.20 \pm 0.09$ \\
September & $0.22 \pm 0.12$ & $0.20 \pm 0.09$ \\
October & $0.21 \pm 0.12$ & $0.19 \pm 0.11$ \\
November & $0.17 \pm 0.12$ & $0.15 \pm 0.09$ \\
December & $0.16 \pm 0.12$ & $0.15 \pm 0.11$ \\
\hline
\end{tabular}

events), on the extensively discussed current anthropogenic climate change. According to the literature, aerosols of anthropogenic origin are mainly composed of fine mode particles (Dubovik et al., 2002; Kaufman et al., 2002). The technique we use to discriminate aerosols of anthropogenic origin was first implemented by Barnaba and Gobbi (2004), showing a good correspondence to the actual aerosol distribution, evaluated using other methods. To investigate the contribution of anthropogenic (mainly of fine mode) aerosols on the total DRE, we used the following method: For each day, we divided the fine mode AOT given in MODIS data by the total AOT, to calculate the fine mode fraction (FMF). For the days that this fraction was greater than 0.7 we assumed that fine mode particles prevailed and that the asymmetry parameter $g$ (taken from MODIS) and single scattering albedo $\omega$ (from AERONET) during these days are characteristic of the fine mode. In this section, we used AERONET Level 1.5 single scattering albedo values, due to lack of sufficient temporal coverage from Level 2.0. For the days that the FMF was less than 0.7 , we assumed a mixed aerosol load. To separate the anthropogenic component from the total aerosol DRE for days with mixed aerosol load, we also needed values of fine mode $g, \omega$ and AOT. While fine mode AOT is already available from MODIS on a daily basis, we used monthly averaged values of fine mode $g$ and $\omega$, computed from the days when the fine mode particles prevailed (FMF greater than $0.7)$.

To investigate the optical characteristics of aerosols during anthropogenic events, we calculated the mean values of AOT, Angstrom exponent, $g$ and $\omega$, with the MODIS FMF ranging between 0.7 and 0.9 . The corresponding values of AOT range between $0.16 \pm 0.08$ and $0.13 \pm 0.07$, compared to the mean $0.21 \pm 19$ for the whole period examined. The Angstrom exponent reaches up to $1.24 \pm 0.68$ for high FMF, while $\omega$ reduces to $0.89 \pm 0.07$, from a mean value of $0.95 \pm 0.02$. The Asymmetry parameter exhibits smaller variance: $0.68 \pm 0.07$ for high anthropogenic aerosol loads, against $0.71 \pm 0.04$ for the whole period. A back-trajectory analysis was conducted for the cases with FMF $>0.9$. The results show that the Balkan area is the main source of these aerosol loads, with secondary sources being South Italy and Western Turkey.

Figure 12 shows the 11-year mean seasonal total aerosol DRE and DRF at the surface (DSR and surface absorption), within the atmosphere and at TOA, derived using Terra MODIS data, while Fig. 13 shows the corresponding results from Aqua MODIS data. Error bars represent the standard deviation for each month. The contribution of natural aerosols to DRE was calculated by subtracting the anthropogenic part from the total.

The results from Terra and Aqua are similar, both showing that the contribution from anthropogenic aerosol particles at the surface (for both downwelling and absorbed radiation) and within the atmosphere increases during summer and secondarily in spring, presenting maximum values mainly in August and April. Aerosols from natural sources show a similar behavior, with peaks appearing in April and late summer. These peaks can be attributed to dust events, which occur mainly during these seasons. At TOA the seasonal variation appears different, with peaks during February and autumn, attributed to both anthropogenic and natural aerosols. The summer peak of the atmospheric absorption, which reaches values almost equal in magnitude with the surface absorption, reduces dramatically the change in TOA outgoing radiation due to aerosols. During their peaks, DRF can reach values of $-24 \mathrm{Wm}^{-2}$ at the surface, $19 \mathrm{Wm}^{-2}$ in the atmosphere and $-5 \mathrm{Wm}^{-2}$ at TOA. The corresponding values for natural aerosol are over $-19 \mathrm{Wm}^{-2}$, $12 \mathrm{Wm}^{-2}$ and $-9 \mathrm{Wm}^{-2}$, respectively. Annual mean values 

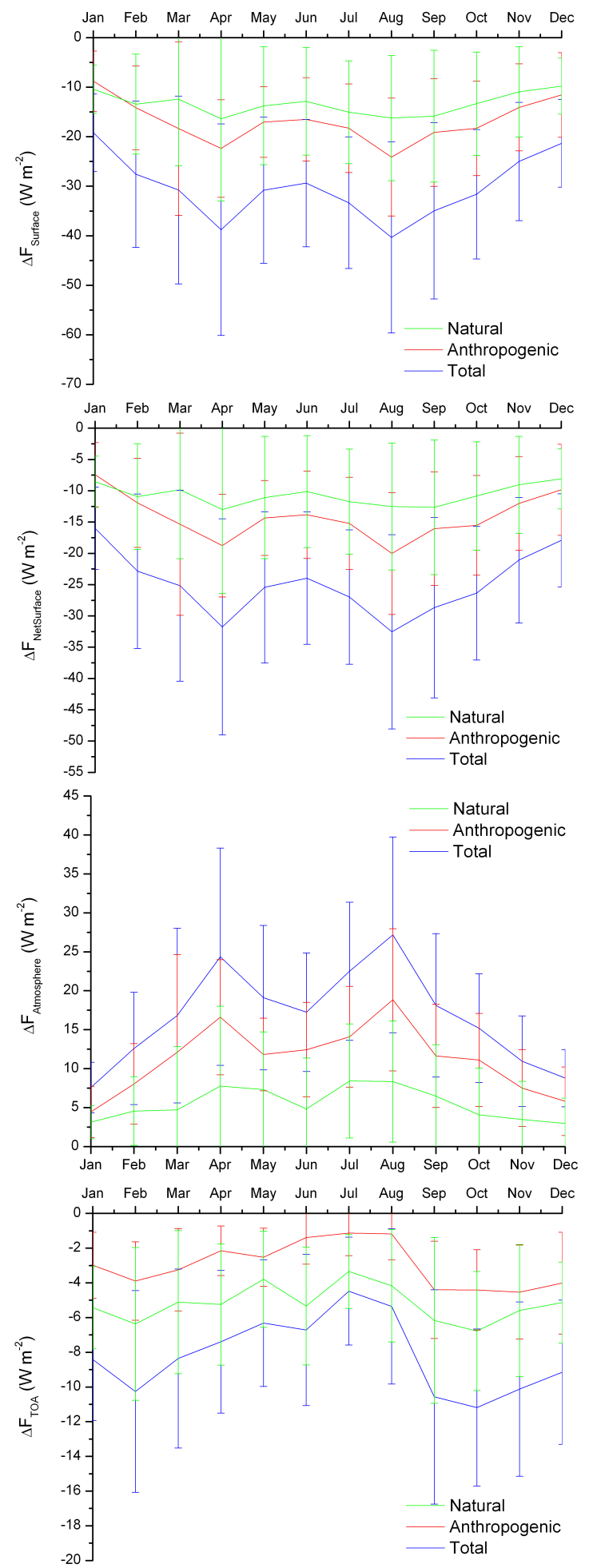

Fig. 12. Mean monthly aerosol DRE and its components (anthropogenic and natural) with standard deviations for the period 20002010 (a) incident at the surface (HCMR Station), (b) absorbed by the surface, (c) in the atmosphere and (d) at TOA, derived using Terra MODIS data.
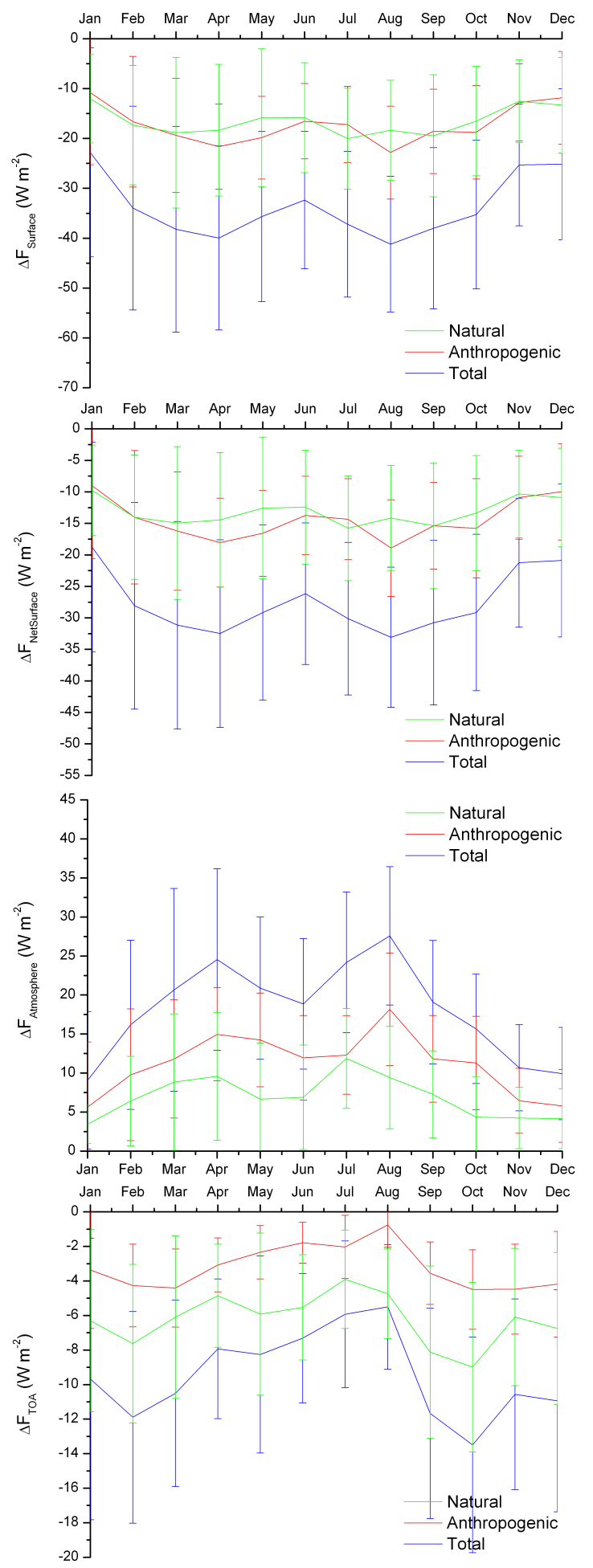

Fig. 13. Mean monthly aerosol DRE and its components (anthropogenic and natural) with standard deviations for the period 2002 2010 (a) incident at the surface (HCMR Station), (b) absorbed by the surface, (c) in the atmosphere and (d) at TOA, derived using Aqua MODIS data. 
and standard deviations of DRF are $-17 \pm 4 \mathrm{Wm}^{-2}$ at the surface, $11 \pm 4 \mathrm{Wm}^{-2}$ in the atmosphere and $-3 \pm 1 \mathrm{Wm}^{-2}$ at TOA, while the corresponding values for natural aerosol are $-15 \pm 3 \mathrm{Wm}^{-2}, 6 \pm 2 \mathrm{Wm}^{-2}$ and $-6 \pm 1 \mathrm{Wm}^{-2}$.

\section{Summary}

We have used a deterministic spectral radiative transfer model, along with various key physical surface and atmospheric parameters, to compute the instantaneous SW radiation budget and aerosol DRE and DRF at the surface, within the atmosphere and at TOA, above FORTH-CRETE AERONET (HCMR) station in Crete, Greece. The data were taken from the MODIS Level 2 data base (Aerosol, Cloud and Atmospheric Profile Products) and were supplemented with data from the FORTH-CRETE AERONET station. The model computations were performed for the 11 year period from 2000 to 2010 , on a $10 \mathrm{~km} \times 10 \mathrm{~km}$ pixel resolution. The results for the DSR were validated against HCMR and Finokalia station data, showing that in general the model is able to predict the DSR in this region, with a negative bias of about 30 to $70 \mathrm{Wm}^{-2}$.

The calculated instantaneous aerosol DRE at the surface, in the atmosphere and at TOA, showed the significance of dust events in the region, when the DRE at the surface can induce surface cooling as high as $-215 \mathrm{Wm}^{-2}$. The maximum values observed, of warming and cooling effects in the atmosphere and at TOA, are approximately 139 and $-46 \mathrm{Wm}^{-2}$, respectively. These large DRE values constitute an important modification factor of the local surface and atmospheric radiation budget which, given the key location of Crete island, is representative of the eastern Mediterranean basin. DRE shows a seasonal pattern, with maximum values during spring, following the corresponding increase of AOT, which is caused by the transportation of African dust that occurs mainly in this season. Nevertheless, a secondary maximum is also observed in summer, associated with anthropogenic aerosols.

The linear regression analysis applied to the monthly mean DRE and the AOT reveals a decreasing trend during the period examined, which is in agreement with similar previous results (Papadimas et al., 2008).

The contribution of anthropogenic aerosols is higher during spring and late summer (April and August), while that from natural sources (mainly dust events) peaks mainly in spring.

In the future, the current version of the model could be used at various sites of specific interest, regarding the direct effect of aerosols on the radiation budget, to investigate the local patterns of the DRE. This is important, especially in view of the assessment of aerosol DRE and DRF under different aerosol regimes, for example urban, remote continental, biomass burning or desert dust. Such future model computations can also benefit from the increased availabil- ity of vertically resolved aerosol information, provided by modern platforms like CALIPSO and CloudSat of A-train satellites. It is also very important to perform validations of computed fluxes against ground stations and satellite measurements, to ensure the validity of the results.

Acknowledgements. This work was supported in part by the Latsis Foundation and by the CityZen project in the frame of the European Union Seventh Framework Programme (Grant Agreement no. 212095).

Edited by: X. Querol

\section{References}

Andreae, T. W., Andreae, M. O., Ichoku, C., Maenhaut, W., Cafmeyer, J., Karnieli, A., and Orlovsky, L.: Light scattering by dust and anthropogenic aerosol at a remote site in the Negev desert, Israel, J. Geophys. Res., 107(D2), 4008, doi:10.1029/2001JD900252, 2002.

Allen, C. W.: Astrophysical Quantities, 3rd Edn., The Athlone Press, University of London, 1976.

Barnaba, F. and Gobbi, G. P.: Aerosol seasonal variability over the Mediterranean region and relative impact of maritime, continental and Saharan dust particles over the basin from MODIS data in the year 2001, Atmos. Chem. Phys., 4, 2367-2391, doi:10.5194/acp-4-2367-2004, 2004.

Bergamo, A., Tafuro, A. M., Kinne, S., De Tomasi, F., and Perrone, M. R.: Monthly-averaged anthropogenic aerosol direct radiative forcing over the Mediterranean based on AERONET aerosol properties, Atmos. Chem. Phys., 8, 6995-7014, doi:10.5194/acp8-6995-2008, 2008.

Bryant, C., Eleftheriadis, K., Smolik, J., Zdimal, V., Mihalopoulos, N., and Colbeck, I.: Optical properties of aerosols over the eastern Mediterranean, Atmospheric Environment, 40, 6229-6244, 2006.

Christopher, S. A. and Zhang, J.: Shortwave aerosol radiative forcing from MODIS and CERES observations over the oceans, Geophys. Res. Lett., 29, 1859, doi:10.1029/2002GL014803, 2002.

Chu, D. A., Kaufman, Y. J., Zibordi, G., Chern, J. D., Mao, J., Li, C., and Holben, B. N.: Global monitoring of air pollution over land from the Earth Observing System-Terra Moderate Resolution Imaging Spectroradiometer (MODIS), J. Geophys. Res., 108, 4661, doi:10.1029/2002JD003179, 2003.

Draxler, R. R. and Hess, G. D.: An overview of the HYSPLIT_4 modelling system for trajectories, dispersion and deposition, Aust. Meteorol. Mag., 47, 295-308, 1998.

Dubovik, O. and King, M. D.: A flexible inversion algorithm for retrieval of aerosol optical properties from Sun and sky radiance measurements, J. Geophys. Res., 105, 20673-20696, doi:10.1029/2000JD900282, 2000.

Dubovik, O., Smirnov, A., Holben, B. N., King, M. D., Kaufman, Y. J., Eck, T. F., and Slutsker, I.: Accuracy assessments of aerosol optical properties retrieved from Aerosol Robotic Network (AERONET) Sun and sky radiance measurements, J. Geophys. Res., 105, 9791-9806, doi:10.1029/2000JD900040, 2000.

Dubovik, O., Holben, B. N., Eck, T. F., Smirnov, A., Kaufman, Y. J., King, M. D., Tanré, D., and Slutsker, I.: Variability of ab- 
sorption and optical properties of key aerosol types observed in worldwide locations, J. Atmos. Sci., 59, 590-608, 2002.

Formenti, P., Andreae, M. O., Andreae, T. W., Galani, E., Vasaras, A., Zerefos, C., Amiridis, V., Orlovsky, L., Karnieli, A., Wendisch, M., Wex, H., Holben, B. N., Maenhaut, W., and Lelieveld, J.: Aerosol optical properties and large-scale transport of air masses: Observations at a coastal and a semiarid site in the eastern Mediterranean during summer 1998, J. Geophys. Res., 106, 9807-9826, doi:10.1029/2000JD900609, 2001.

Forster, P., Ramaswamy, V., Artaxo, P., Berntsen, T., Betts, R., Fahey, D. W., Haywood, J., Lean, J., Lowe, D. C., Myhre, G., Nganga, J., Prinn, R., Raga, G., Schulz, M., and Van Dorland, R.: Changes in Atmospheric Constituents and in Radiative Forcing, in: Climate Change 2007: The Physical Science Basis, Contribution of Working Group I to the Fourth Assessment Report of the Intergovernmental Panel on Climate Change, edited by: Solomon, S., Qin, D., Manning, M., Chen, Z., Marquis, M., Averyt, K. B., Tignor, M. and Miller, H. L., Cambridge University Press, Cambridge, United Kingdom and New York, NY, USA, 2007.

Fotiadi, A., Hatzianastassiou, N., Drakakis, E., Matsoukas, C., Pavlakis, K. G., Hatzidimitriou, D., Gerasopoulos, E., Mihalopoulos, N., and Vardavas, I.: Aerosol physical and optical properties in the Eastern Mediterranean Basin, Crete, from Aerosol Robotic Network data, Atmos. Chem. Phys., 6, 53995413, doi:10.5194/acp-6-5399-2006, 2006.

Gómez-Amo, J. L., Pinti, V., Di Iorio, T., Di Sarra, A., Meloni, D., Becagli, S., Bellantone, V., Cacciani, M., Fuà, D., and Perrone, M. R.: The June 2007 Saharan dust event in the central Mediterranean: Observations and radiative effects in marine, urban, and sub-urban environments, Atmospheric Environment, 45, 53855393, doi:10.1016/j.atmosenv.2011.06.045, 2011.

Gueymard, C.: The Sun's total and spectral irradiance for solar energy applications and solar radiation models, Solar Energy, 76, 423-453, 2004.

Hartman, D. L.: Global Physical Climatology, Academic Press, 411 pp., 1994.

Hatzianastassiou, N. and Vardavas, I.: Shortwave radiation budget of the Northern Hemisphere using International Satellite Cloud Climatology Project and NCEP/NCAR climatological data, J. Geophys. Res., 104, 24401-24421, 1999.

Hatzianastassiou, N. and Vardavas, I.: Shortwave radiation budget of the Southern Hemisphere using ISCCP C2 and NCEP/NCAR climatological data, J. Climate, 14, 4319-4329, 2001.

Hatzianastassiou, N., Fotiadi, A., Matsoukas, Ch., Pavlakis, K., Drakakis, E., Hatzidimitriou, D., and Vardavas, I.: Longterm global distribution of earth's shortwave radiation budget at the top of atmosphere, Atmos. Chem. Phys., 4, 1217-1235, doi:10.5194/acp-4-1217-2004, 2004a.

Hatzianastassiou, N., Katsoulis, B., and Vardavas, I.: Global distribution of aerosol direct radiative forcing in the ultraviolet and visible arising under clear skies, Tellus, 56B, 51-71, 2004b.

Hatzianastassiou, N., Matsoukas, C., Fotiadi, A., Pavlakis, K. G., Drakakis, E., Hatzidimitriou, D., and Vardavas, I.: Global distribution of Earth's surface shortwave radiation budget, Atmos. Chem. Phys., 5, 2847-2867, doi:10.5194/acp-5-2847-2005, 2005.

Hatzianastassiou, N., Matsoukas, C., Fotiadi, A., P. W. Stackhouse Jr., Koepke, P., Pavlakis, K. G., and Vardavas, I.: Modelling the direct effect of aerosols in the solar near-infrared on a planetary scale, Atmos. Chem. Phys., 7, 3211-3229, doi:10.5194/acp-73211-2007, 2007.

Haywood, J., Francis, P., Osborne, S., Glew, M., Loeb, N., Highwood, E., Tanré, D., Myhre, G., Formenti, P., and Hirst, E.: Radiative properties and direct radiative effect of Saharan dust measured by the C-130 aircraft during SHADE: 1. Solar spectrum, J. Geophys. Res., 108, 8577, doi:10.1029/2002JD002687, 2003.

Holben, B. N., Eck, T. F., Slutsker, I., Tanré, D., Buis, J. P., Setzer, A., Vermote, E., Reagan, J. A., Kaufman, Y. J., Nakajima, T., Lavenu, F., Jankowiak, I., and Smirnov, A.: AERONET - A federated instrument network and data archive for aerosol characterization, Remote Sens. Environ., 66, 1-16, 1998.

Holben, B. N., Tanré, D., Smirnov, A., Eck, T. F., Slutsker, I., Abuhassan, N., Newcomb, W. W., Schafer, J., Chatenet, B., Lavenue, F., Kaufman, Y. J., Vande Castle, J., Setzer, A., Markham, B., Clark, D., Frouin, R., Halthore, R., Karnieli, A., O'Neill, N. T., Pietras, C., Pinker, R. T., Voss, K., and Zibordi, G.: An emerging ground-based aerosol climatology: Aerosol Optical Depth from AERONET, J. Geophys. Res., 106, 12067-12097, 2001.

Ichoku, C., Chu, D. A., Mattoo, S., Kaufman, Y. J., Remer, L. A., Tanré, V., Slutsker, I., and Holben, B. N.: A spatio-temporal approach for global validation and analysis of MODIS aerosol products, Geophys. Res. Lett., 29, 8006, doi:10.1029/2001GL013206, 2002.

IPCC, 2007: Climate Change 2007: The Physical Science Basis. Contribution of Working Group I to the Fourth Assessment Report of the Intergovernmental Panel on Climate Change, edited by: Solomon, S., Qin, D., Manning, M., Chen, Z., Marquis, M., Averyt, K. B., Tignor, M., and Miller, H. L., Cambridge University Press, Cambridge, United Kingdom and New York, NY, USA, 996 pp., 2007.

Joseph, J. H., Wiscombe, W. J., and Weinmann, J. A.: The DeltaEddington approximation of radiative flux transfer, J. Atmos. Sci., 33, 2452-2459, 1976.

Kalivitis, N., Gerasopoulos, E., Vrekoussis, M., Kouvarakis, G., Kubilay, N., Hatzianastassiou, N., Vardavas, I., and Mihalopoulos, N.: Dust transport over the eastern Mediterranean derived from Total Ozone Mapping Spectrometer, Aerosol Robotic Network, and surface measurements, J. Geophys. Res., 112, D03202, doi:10.1029/2006JD007577, 2007.

Kaskaoutis, D. G., Kambezidis, H. D., Nastos, P. T., and Kosmopoulos, P. G.: Study on an intense dust storm over Greece, Atmospheric Environment, 42, 6884-6896, doi:10.1016/j.atmosenv.2008.05.017, 2008.

Kaufman, Y. J., Tanré, D., Remer, L. A., Vermote, E. F., Chu, A., and Holben, B. N.: Operational remote sensing of tropospheric aerosol over land from EOS moderate resolution imaging spectroradiometer, J. Geophys. Res., 102, 17051-17067, 1997.

Kaufman, Y. J., Tanré, D., and Boucher, O.: A satellite view of aerosols in the climate system, Nature, 419, 215-223, 2002.

King, M. D., Menzel, W. P., Kaufman, Y. J., Tanré, D., Gao, B. C., Platnick, S., Ackerman, S. A., Remer, L. A., Pincus, R., and Hubanks, P. A.: Cloud and aerosol properties, precipitable water, and profiles of temperature and humidity from MODIS. IEEE Trans., Geosci. Remote Sens., 41, 442-458, 2003.

Keil, A. and Haywood, J.: Solar radiative forcing by biomass burning aerosol particles during SAFARI-2000: A case study based on measured aerosol and cloud properties, J. Geophys. Res., 108, 
8467, doi:10.1029/2002JD002315, 2003.

Kleidman, R. G., O’Neill, N. T., Remer, L. A., Kaufman, Y. J., Eck, T. F., Tanré, D., Dubovik, O., and Holben, B. N.: Comparison of Moderate Resolution Imaging Spectroradiometer (MODIS) and Aerosol Robotic Network (AERONET) remote-sensing retrievals of aerosol fine mode fraction over ocean, J. Geophys. Res., 110, D22205, doi:10.1029/2005JD005760, 2005

Kondratyev, K. Y.: Radiation Characteristics of the Atmosphere and the Earth's surface, Amerind, New Delhi, 580 pp., 1973.

Lelieveld, J., Berresheim, H., Borrmann, S., Crutzen, P. J., Dentener, F. J., Fischer, H., Feichter, J., Flatau, P. J., Heland, J., Holzinger, R., Korrmann, R., Lawrence, M. G., Levin, Z., Markowicz, K. M., Mihalopoulos, N., Minikin, A., Ramanathan, V., de Reus, M., Roelofs, G. J., Scheeren, H. A., Sciare, J., Schlager, H., Schultz, M., Siegmund, P., Steil, B., Stephanou, E. G., Stier, P., Traub, M., Warneke, C., Williams, J., and Ziereis, H.: Global Air Pollution Crossroads over the Mediterranean, Science, 298, 5594, 794-799, 2002.

Mallet, M., Tulet, P., Serça, D., Solmon, F., Dubovik, O., Pelon, J., Pont, V., and Thouron, O.: Impact of dust aerosols on the radiative budget, surface heat fluxes, heating rate profiles and convective activity over West Africa during March 2006, Atmos. Chem. Phys., 9, 7143-7160, doi:10.5194/acp-9-7143-2009, 2009.

Matsoukas, C., Benas, N., Hatzianastassiou, N., Pavlakis, K. G., Kanakidou, M., and Vardavas, I.: Potential evaporation trends over land between 19832008: driven by radiative or turbulent fluxes?, Atmos. Chem. Phys. Discuss., 11, 10935-10972, doi:10.5194/acpd-11-10935-2011, 2011.

Meloni, D., di Sarra, A., Di Iorio, T., and Fiocco, G.: Influence of the vertical profile of Saharan dust on the visible direct radiative forcing, J. Quant. Spectrosc. Ra., 93, 347-413, 2005.

Mihalopoulos, N., Stephanou, E., Pilitsidis, S., Kanakidou, M., and Bousquet, P.: Atmospheric aerosol composition above the Eastern Mediterranean region, Tellus, 49B, 314-326, 1997.

Papadimas, C. D., Hatzianastassiou, N., Mihalopoulos, N., Querol, X., and Vardavas, I.: Spatial and temporal variability in aerosol properties over the Mediterranean basin based on 6year (2000-2006) MODIS data, J. Geophys. Res., 113, D11205, doi:10.1029/2007JD009189, 2008.

Peng, L. I., Chou, M.-D., and Arking, A.: Climate studies with a multi-layer energy balance model, Part I: Model description and sensitivity to the solar constant, J. Atmos. Sci., 39, 2639-2656, 1982.

Remer, L. A., Tanré, D., Kaufman, Y. J., Ichoku, C., Mattoo, S., Levy, R., Chu, D. A., Holben, B. N., Dubovik, O., Smirnov, A., Martins, J. V., Li, R.-R., and Ahmad, Z.: Validation of MODIS aerosol retrieval over ocean, Geophys. Res. Lett., 29, MOD03, doi:10.1029/2001GL013204, 2002.
Remer, L. A., Kaufman, Y. J., Tanré, D., Mattoo, S., Chu, D. A., Martins, J. V., Li, R. R., Ichoku, C., Levy, R. C., Kleidman, R. G., Eck, T. F., Vermote, E., and Holben, B. N.: The MODIS aerosol algorithm, products and validation, J. Atmos. Sci., 62, 947-973, 2005.

Sander, S. P., Friedl, R. R., Ravishankara, A. R., Golden, D. M., Kolb, C. E., Kurylo, M. J., Molina, J., Moortgat, G. K., KellerRudek, H., Finlayson-Pitts, B. J., Wine, P. H., Huie, R. E., and Orkin, V. L.: Chemical Kinetics and Photochemical Data for Use in Atmospheric Studies, Evaluation Number 15, Jet Propulsion Laboratory Publication 06-2, California Institute of Technology, Pasadena, 2006.

Santese, M., De Tomasi, F., and Perrone, M. R.: Moderate Resolution Imaging Spectroradiometer (MODIS) and Aerosol Robotic Network (AERONET) retrievals during dust outbreaks over the Mediterranean, J. Geophys. Res., 112, D18201, doi:10.1029/2007JD008482, 2007.

Shettle, E. P. and Weinmann, J. A.: The transfer of solar irradiance through inhomogeneous turbid atmospheres evaluated by Eddington's approximation, J. Atmos. Sci., 27, 1048-1055, 1970.

Tafuro, A. M., Barnaba, F., De Tomasi, F., Perrone, M. R., and Gobbi, G. P.: Saharan dust particle properties over the central Mediterranean, Atmos. Res., 81, 67-93, doi:10.1016/j.atmosres.2005.11.008, 2006.

Tanré, D., Kaufman, Y. J., Herman, M., and Mattoo, S.: Remote sensing of aerosol properties over oceans using the MODIS/EOS spectral radiances, J. Geophys. Res., 102, 16971-16988, 1997.

Vardavas, I. and Carver, J. H.: Solar and terrestrial parameterizations for radiative convective models, Planet. Space Sci., 32, 1307-1325, 1984.

Vardavas, I. M. and Koutoulaki, K.: A model for the solar radiation budget of the Northern Hemisphere: Comparison with Earth Radiation Budget Experiment data, J. Geophys. Res., 100, 7303 7314, 1995.

Vardavas, I. M. and Taylor, F. W.: Radiation and Climate: Atmospheric energy budget from satellite remote sensing, International Series of Monographs on Physics, 138, Oxford University Press, Oxford, UK, 2011.

Willson, R. C.: Total solar irradiance trend during solar cycles 21 and 22, Science, 277, 1963-1965, 1997. 